\title{
Modeling the radiative effects of biomass burning aerosols on carbon fluxes in the Amazon region
}

\author{
Demerval S. Moreira ${ }^{1,2}$, Karla M. Longo ${ }^{3, a}$, Saulo R. Freitas ${ }^{3, a}$, Marcia A. Yamasoe ${ }^{4}$, Lina M. Mercado ${ }^{5,6}$, \\ Nilton E. Rosário ${ }^{7}$, Emauel Gloor ${ }^{8}$, Rosane S. M. Viana ${ }^{9}$, John B. Miller ${ }^{10}$, Luciana V. Gatti ${ }^{11,12}$, \\ Kenia T. Wiedemann ${ }^{13}$, Lucas K. G. Domingues ${ }^{11,12}$, and Caio C. S. Correia ${ }^{11,12}$ \\ ${ }^{1}$ Universidade Estadual Paulista (UNESP), Faculdade de Ciências, Bauru, SP, Brazil \\ ${ }^{2}$ Centro de Meteorologia de Bauru (IPMet), Bauru, SP, Brazil \\ ${ }^{3}$ Centro de Previsão de Tempo e Estudos Climáticos, Instituto Nacional de Pesquisas Espaciais (INPE), \\ Cachoeira Paulista, SP, Brazil \\ ${ }^{4}$ Departamento de Ciências Atmosféricas do Institudo de Astronomia, Geofísica e Ciências Atmosféricas, \\ Universidade de São Paulo (USP), São Paulo, SP, Brazil \\ ${ }^{5}$ Geography, College of Life and Environmental Sciences, University of Exeter, Exeter, UK \\ ${ }^{6}$ Centre for Ecology and Hydrology (CEH), Wallingford, UK \\ ${ }^{7}$ Universidade Federal de São Paulo (UNIFESP), Campus Diadema, Diadema, SP, Brazil \\ ${ }^{8}$ School of Geography, University of Leeds, Woodhouse Lane, Leeds, UK \\ ${ }^{9}$ Departamento de Matemática, Universidade Federal de Viçosa (UFV), Viçosa, MG, Brazil \\ ${ }^{10}$ Global Monitoring Division, Earth System Research Laboratory, National Oceanic and Atmospheric Administration \\ (NOAA), Boulder, Colorado 80305, USA \\ ${ }^{11}$ Centro de Ciências do Sistema Terrestre, Instituto Nacional de Pesquisas Espaciais (INPE), São José dos Campos, SP, Brazil \\ ${ }^{12}$ Instituto de Pesquisas Energéticas e Nucleares (IPEN), Comissão Nacional de Energia Nuclear (CNEN), São Paulo, Brazil \\ ${ }^{13}$ Department of Ecology and Evolutionary Biology, University of Arizona, Tucson, AZ, USA \\ anow at: Universities Space Research Association/Goddard Earth Sciences Technology and Research (USRA/GESTAR), \\ Global Modeling and Assimilation Office, NASA Goddard Space Flight Center, Greenbelt, MD, USA
}

Correspondence: Demerval S. Moreira (demerval@fc.unesp.br)

Received: 21 December 2016 - Discussion started: 20 February 2017

Revised: 20 July 2017 - Accepted: 1 August 2017 - Published: 12 December 2017

\begin{abstract}
Every year, a dense smoke haze covers a large portion of South America originating from fires in the Amazon Basin and central parts of Brazil during the dry biomass burning season between August and October. Over a large portion of South America, the average aerosol optical depth at $550 \mathrm{~nm}$ exceeds 1.0 during the fire season, while the background value during the rainy season is below 0.2. Biomass burning aerosol particles increase scattering and absorption of the incident solar radiation. The regional-scale aerosol layer reduces the amount of solar energy reaching the surface, cools the near-surface air, and increases the diffuse radiation fraction over a large disturbed area of the Amazon rainforest. These factors affect the energy and $\mathrm{CO}_{2}$ fluxes at the surface. In this work, we applied a fully integrated at-
\end{abstract}

mospheric model to assess the impact of biomass burning aerosols in $\mathrm{CO}_{2}$ fluxes in the Amazon region during 2010. We address the effects of the attenuation of global solar radiation and the enhancement of the diffuse solar radiation flux inside the vegetation canopy. Our results indicate that biomass burning aerosols led to increases of about $27 \%$ in the gross primary productivity of Amazonia and $10 \%$ in plant respiration as well as a decline in soil respiration of $3 \%$. Consequently, in our model Amazonia became a net carbon sink; net ecosystem exchange during September 2010 dropped from +101 to $-104 \mathrm{TgC}$ when the aerosol effects are considered, mainly due to the aerosol diffuse radiation effect. For the forest biome, our results point to a dominance of the diffuse radiation effect on $\mathrm{CO}_{2}$ fluxes, reaching a balance 
of 50-50\% between the diffuse and direct aerosol effects for high aerosol loads. For C3 grasses and savanna (cerrado), as expected, the contribution of the diffuse radiation effect is much lower, tending to zero with the increase in aerosol load. Taking all biomes together, our model shows the Amazon during the dry season, in the presence of high biomass burning aerosol loads, changing from being a source to being a sink of $\mathrm{CO}_{2}$ to the atmosphere.

\section{Introduction}

The austral winter in most of South America is typically dry with extensive vegetation fires, mostly human induced, in areas of deforestation and agricultural or pasture land management. The fire activity, especially in Amazonia and cerrado areas (a savanna-like biome), usually lasts for at least 3 months from August to October every year and has typically been called the "biomass burning season". Fire emissions can be a significant source of carbon dioxide $\left(\mathrm{CO}_{2}\right)$ to the atmosphere (e.g., Gatti et al., 2014) and a major source of several other trace gases to the atmosphere (Andreae et al., 2002). In addition to trace gases, vegetation fires also produce a large amount of aerosol particles, in particular in the fine mode, which on average contribute to at least $90 \%$ of the total AOD in the visible spectrum in the case of South American regional smoke (Reid et al., 2005; Rosário, 2011). The resulting smoke haze typically covers areas of several million square kilometers over South America (Prins et al., 1998). Outside the biomass burning season, mean AOD in the visible spectrum varies from 0.10 to $\sim 0.15$ across the Amazon rainforest and from 0.12 to $\sim 0.20$ in the cerrado areas (Schafer et al., 2008; Rosario, 2011). At the peak of the burning season, during September, monthly mean AOD can reach values up to 10 and 5 times higher than the clean wet season values in the southern and the northern areas, respectively (Schafer et al., 2008; Rosário, 2011). The Ångström exponent (AE), an optical property used to characterize aerosol particle size based on the spectral dependence of AOD, increases from $\sim 0.60$ during the clean period to 2.0 during the peak of the burning season (Schafer et al., 2008). Such a high value of $\mathrm{AE}$ is representative of air masses dominated by fine-mode particles, a major feature of the South American regional plume. Low values of $\mathrm{AE}$ indicate a dominance of coarse-mode particles, a characteristic of the pristine region of the Amazon dominated by biogenic particles. The absorption characteristics of the particles, expressed by the optical property single scattering albedo (SSA), ranges in the southern portion of the Amazon forest during the burning season from 0.92 to 0.93 at $550 \mathrm{~nm}$ and reveal a dominance of moderate absorbing particles (Schafer et al., 2008). This is unlike those from cerrado, which are highly absorbing and present low values of SSA $(\sim 0.89 \pm 0.04)$. Cerrado has a substantially lower SSA than the mean values in the southern Ama- zon forest due to the higher fraction of flaming-phase combustion, which is typical of savanna-like vegetation (Schafer et al., 2008).

In Amazonia under heavy smoke conditions, surface cooling can reach $3^{\circ} \mathrm{C}$, restraining the turbulent flows and consequently the evapotranspiration of water and sensible heat flux. Thus, the result is a drier and shallower boundary layer inhibiting the formation and development of convective clouds and hence decreasing precipitation (Yu et al., 2002). In particular, biomass burning aerosols reduce the net direct solar radiation reaching the surface, while they increase the diffuse fraction of solar radiation. The diffuse fraction of photosynthetically active radiation (PAR) can increase from about $19 \%$, which is the typical value for a clean atmosphere scenario, up to $80 \%$ under biomass burning conditions (Yamasoe et al., 2006). Biomass burning aerosols also act as cloud condensation nuclei affecting cloud microphysical properties and therefore change the radiation budget and hydrological cycle over disturbed areas (Kaufman, 1995; Rosenfeld, 1999; Andreae et al., 2004; Koren et al., 2004).

Changes in the total downward solar irradiance at the surface usually does not impact the photosynthetic activity of the leaves on the top of the forest canopy because those are usually light saturated around midday, closing the plant stomata. On the other hand, sub-canopy leaves typically remain under light-deficit conditions and do not fully achieve their photosynthetic potential. Thus, increasing the diffuse light that penetrates deeper into the canopy increases PAR availability to the sub-canopy leaves and the rate of photosynthesis, and consequently atmospheric carbon assimilation (Baldocchi, 1997; Misson et al., 2005; Oliveira et al., 2007; Knohl and Baldocchi, 2008; Mercado et al., 2009; Doughty et al., 2010; Kanniah et al., 2012; Rap et al., 2015). However, the increase in the diffuse radiation is also accompanied by a decrease in the total radiation, therefore defining an optimal diffuse to total radiation fraction that allows a maximum of carbon assimilation. Under heavy pollution or cloudy skies, plant productivity increases with the diffuse radiation, though it is still insufficient to compensate for the reduction in the total irradiance reaching the surface. Additionally, other authors suggest that the contribution of biomass burning aerosols to $\mathrm{CO}_{2}$ assimilation can also be due to the cooling of the air (Min, 2005; Doughty et al., 2010; Steiner and Chameides, 2011), causing an increase in relative humidity (Collatz et al., 1991) near the earth's surface, which reduces plant respiration and thermal stress of the leaves. Indeed, field observations indicate that tropical forest productivity is highly sensitive to temperature variations (Feeley et al., 2007), with $\mathrm{CO}_{2}$ assimilation decreasing sharply during warmer periods. Doughty et al. (2010) estimated that under dense biomass burning conditions in Amazonia, $80 \%$ of the increase in $\mathrm{CO}_{2}$ absorption is due to the increase in sub-canopy light (diffuse radiation), and only $20 \%$ is due to the reduction in the canopy temperature. The gross primary production (GPP) is the total carbon uptake resulting from 
photosynthesis by plants, especially leaves, in an ecosystem over a land area. GPP responds to the amount of photosynthetically active radiation of solar energy reaching the plants, given limitations of soil moisture and nutrients. A modeling study at the global scale exploring the aerosol impact on GPP concluded that the positive effect of the diffuse radiation increase was indeed larger than the negative effect of the irradiance reduction (Mercado et al., 2009). JULES simulations forced with aerosol fields from the Hadley Centre Global Environment Model version 2 (HadGEM2) by these authors pointed to an increase in the diffuse fraction of irradiance and a consequent increase in the global carbon uptake of $23.7 \%$ from 1960 to 1999. Rap et al. (2015) also used JULES but with a different offline aerosol model: the 3-D GLObal Model of Aerosol Processes (GLOMAP; Mann et al., 2010). They estimated that the biomass burning aerosols affected the diffuse radiation by 3.4 to $6.8 \%$ and increased the net primary production (NPP) of 1.4 to $2.8 \%$ in Amazonia during the period between 1998 and 2007. The biomass burning aerosol indirect effect will also impact $\mathrm{CO}_{2}$ fluxes by changing the amount of rain (and soil moisture), solar radiation availability, and diffuse fraction. Lastly, vegetation fires also emit ozone precursors and promote tropospheric ozone production and surface deposition. Ozone is highly phytotoxic, damaging plant stomata and reducing $\mathrm{CO}_{2}$ uptake (Sitch et al., 2007).

Motivated by all these previously cited recent observational and theoretical studies that have demonstrated the impacts of aerosols on $\mathrm{CO}_{2}$ fluxes, we applied an integrated in-line numerical atmospheric modeling system to explore the following scientific questions: what is the relative role of the main processes between soil, vegetation, and the atmosphere controlling the carbon cycle in Amazonia? What are the effects of biomass burning aerosols for each of these processes? What is the net aerosol effect on $\mathrm{CO}_{2}$ fluxes? What is the relative effect of the direct interaction of aerosol radiation against the aerosol impact on the diffuse fraction? What is the regional dimension of the aerosol impact on $\mathrm{CO}_{2}$ fluxes? Finally, how well can a state-of-the-art chemical transport model (CTM) reproduce $\mathrm{CO}_{2}$ fluxes and mixing ratio observations over the Amazon Basin?

The structure of this paper is as follows. In Sect. 2.1, we present a description of the most relevant aspects of the integrated atmospheric modeling system for this application. The adopted model configuration and the input data sets, including emissions and boundary conditions, are described in Sect. 2.2. The observational data sets, both from direct and remote sensing observations, used for model evaluation and analyses are described in Sect. 2.3. Model results are presented and discussed in Sect. 3. Section 3.1 provides an overview of the meteorology and fire activity in Amazonia during the study period, including both model results and observations. We then follow up in Sect. 3.2 with the model results for the regional biomass burning plume. Finally, in Sect. 3.3 we examine the model results for energy and $\mathrm{CO}_{2}$ fluxes related to several surface-atmosphere interaction processes and the aerosol biomass burning impacts on them. The main results are summarized in Sect. 4.

\section{Methods and data sets}

\subsection{Description of the relevant parts of the modeling system}

In this work, we employed the integrated atmosphericchemistry model BRAMS version 5.0 (Brazilian developments on the Regional Atmospheric Modeling System; Freitas et al., 2005, 2009, 2017), which has been coupled in a two-way mode with the Joint UK Land Environment Simulator v3.0 (JULES), the land surface scheme of the UK Hadley Centre Earth System Model, as described in Moreira et al. (2013). The coupling is two-way in the sense that, for each model time step, the atmospheric component provides to JULES the current near-surface wind speed, air temperature, pressure, condensed water and downward radiation fluxes, and water vapor and carbon dioxide mixing ratios. After its processing, JULES advances its state variables over the time step and feeds back the atmospheric component with sensible and latent heat and momentum surface fluxes, upward shortwave and longwave radiation fluxes, and a set of trace gas fluxes.

\subsubsection{Biosphere model: the Joint UK Land Environment Simulator (JULES)}

JULES simulates the exchange of carbon, momentum, and energy between the land surface and the atmosphere. Additionally, it represents subsurface hydrological processes, plant photosynthesis and respiration, and vegetation and soil dynamics (Best et al., 2011; Clark et al., 2011).

Atmospheric aerosols influence ecosystem functioning via effects on GPP from changes in the quality and quantity of radiation but also indirectly via temperature effects on GPP and plant and heterotrophic respiration. The photosynthesis radiation scheme in JULES accounts for the effects of diffuse radiation on canopy photosynthesis by splitting direct and diffuse radiation and sunlit and shaded leaves at each canopy layer. Specifically, the multilayer radiation scheme includes an explicit calculation of the absorption and scattering of the direct beam and the diffuse radiation fluxes in both visible and near-infrared wavebands at each canopy layer using the two-stream approach from Sellers (1985). Additionally, the attenuation of non-scattered incident direct beam radiation (sun flecks) is calculated using the approach by Dai et al. (2004). At each canopy layer, JULES estimates the fraction of absorbed direct and diffuse photosynthetic active radiation (PAR), thus providing a vertical profile of intercepted radiation fields, which allows for the calculation of photosynthesis at each canopy level. At each canopy layer, the fraction of sunlit and shaded leaves is estimated as a function of the 


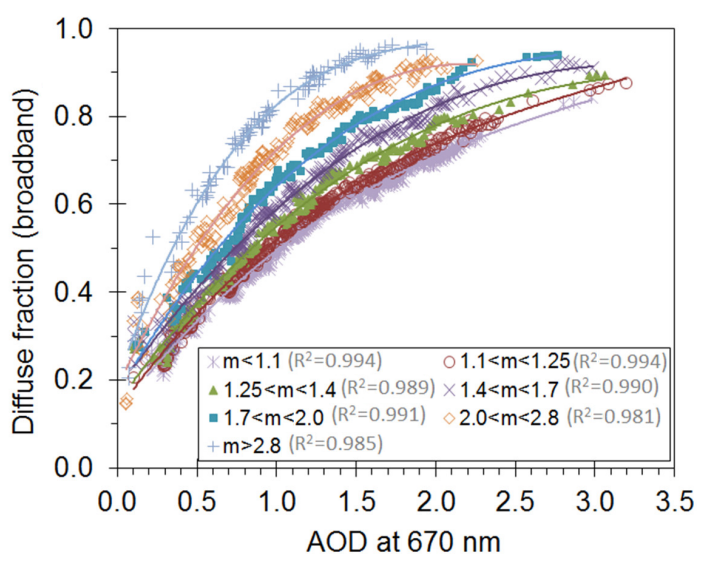

Figure 1. Fraction of diffuse broadband solar irradiance reaching the surface as a function of AOD at $670 \mathrm{~nm}$ and optical air mass intervals $(m)$.

canopy beam radiation extinction coefficient (as explained in Clark et al., 2011), and it is assumed that shaded leaves absorb only diffuse radiation and sunlit leaves absorb all types of radiation. Photosynthesis at each canopy layer is then estimated as the sum of sunlit and shaded leaf photosynthesis weighed by their respective fraction. Total canopy photosynthesis is estimated as the sum of the leaf-level fluxes in each layer scaled by the leaf area of each canopy layer.

Temperature effects on photosynthesis are simulated in JULES via biochemistry, leaf respiration, and effects of vapor pressure deficit (VPD) on stomatal conductance in response to the temperature (see details in Clark et al., 2011). The temperature response of leaf respiration is linked to the temperature response of maximum carboxylation activity of Rubisco (Vcmax) in JULES, which is described by a peaked response function. The temperature response of remaining maintenance respiration components is also simulated using the leaf respiration temperature function. Growth respiration is estimated as a proportion of net primary productivity (NPP). Heterotrophic respiration is simulated either using a Q10 temperature function or a RothC temperature function (Jenkinson et al., 1990 as described in Clark et al., 2011).

Evaluation of the skill of JULES in simulating GPP under highly direct and highly diffuse radiation conditions has been tested against flux sites in the Amazon and in temperate forest sites where direct and diffuse radiation measurements are available. This is shown in Fig. 2 of Rap et al. (2015) at Tapajós and French Guiana in the Amazon and at two temperate forest sites in Mercado et al. (2009; Fig. 1). Investigation of the response of photosynthesis to changes in direct and diffuse radiation across relevant plant functional types for the Amazon region is carried out within this study.

\subsubsection{Atmospheric model: Brazilian developments on the Regional Atmospheric Modeling System (BRAMS)}

BRAMS is in-line coupled with a Eulerian transport model (CCATT) suitable to simulate emission, transport, dispersion, chemical transformation, and removal processes associated with trace gases and aerosols (Longo et al., 2013). In CCATT, aerosol and trace gas transport runs consistently inline with the atmospheric state evolution using the BRAMS dynamic and physical parameterizations. The tracer mass mixing ratio, which is a prognostic variable, includes the effects of sub-grid-scale turbulence in the planetary boundary layer (PBL) and convective transport by shallow and deep moist convection in addition to grid-scale advection transport. For gaseous species, CCATT-BRAMS can in principle employ several gaseous chemical mechanisms. However, for this study, only carbon monoxide ( $\mathrm{CO}), \mathrm{CO}_{2}$, and aerosol particles (biomass burning type) were emitted and transported. The physical removal processes (dry and wet deposition) were applied to all three tracers, and effective lifetimes were applied to $\mathrm{CO}$ and aerosol particles. As the modeling of aerosol biomass burning particles is the focus of the present study, only biomass burning emission sources were considered.

The BRAMS model parameterizations chosen for the simulations performed in this work are described as follows. The parameterization for the unresolved turbulence in the PBL was based on the Mellor and Yamada (1982) formulation, which predicts turbulent kinetic energy (TKE). For the microphysics, we used the single-moment bulk microphysics parameterization, which includes cloud water, rain, pristine ice, snow, aggregates, graupel, and hail (Walko et al., 1995). It includes prognostic equations for the mixing ratios of rain and each ice category of total water and the concentration of pristine ice. Water vapor and cloud liquid mixing ratios are diagnosed from the prognostic variables using the saturation mixing ratio of liquid water. The deep and shallow cumulus convection schemes are based on the mass-flux approach and described in Grell and Freitas (2014).

The radiation scheme is a modified version of the Community Aerosol and Radiation Model for Atmospheres (CARMA; Toon et al., 1988), which includes the aerosolradiation interaction with feedback to the model heating rates (Longo et al., 2013; Rosário et al., 2013). In addition, we included in CARMA a parameterization to calculate the diffuse fraction of solar irradiance specific to biomass burning aerosols in Amazonia. This parameterization was based on measurements of broadband and narrowband solar global and diffuse irradiance components performed with a multifilter rotating shadowband radiometer (MFRSR; Harrison et al., 1994). With the narrowband measurements centered at $415,670,870$, and $1036 \mathrm{~nm}$, AOD was estimated following the methodology of Harrison and Michalsky (1994) and Rosário et al. (2008). The measurements were performed at 
Table 1. Parameters for a third-degree polynomial fit to the diffuse fraction of broadband solar irradiance reaching the surface as a function of AOD at $670 \mathrm{~nm}$ for distinct air mass intervals.

\begin{tabular}{lrrrrr}
\hline Optical air mass & $a$ & $b$ & $c$ & $d$ & $R^{2}$ \\
\hline$m \leq 1.10$ & 0.0115 & -0.1115 & 0.4693 & 0.1258 & 0.994 \\
$1.10<m \leq 1.25$ & 0.0129 & -0.1235 & 0.4997 & 0.1304 & 0.994 \\
$1.25<m \leq 1.40$ & 0.0075 & -0.1087 & 0.5035 & 0.1477 & 0.989 \\
$1.40<m \leq 1.70$ & 0.0052 & -0.1031 & 0.5077 & 0.1795 & 0.990 \\
$1.70<m \leq 2.00$ & 0.0144 & -0.1634 & 0.6207 & 0.1696 & 0.991 \\
$2.00<m \leq 2.80$ & 0.0166 & -0.2237 & 0.7458 & 0.1851 & 0.981 \\
$m>2.80$ & 0.0736 & -0.4631 & 1.0152 & 0.2005 & 0.985 \\
\hline
\end{tabular}

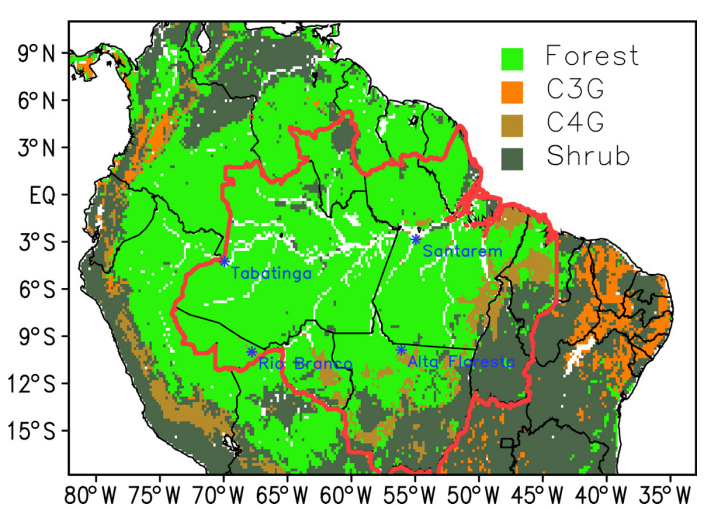

Figure 2. Model domain with the map of land cover used in BRAMS, with the color scale depicting the dominant biomes. The red contour line on the map delimits the LBAR and the locations of $\mathrm{CO}_{2}$ and $\mathrm{CO}$ airborne measurements: Santarém, PA $\left(2.85^{\circ} \mathrm{S}\right.$, $\left.54.95^{\circ} \mathrm{W}\right)$; Rio Branco, AC $\left(9.99^{\circ} \mathrm{S}, 67.80^{\circ} \mathrm{W}\right)$; Alta Floresta, MT $\left(9.87^{\circ} \mathrm{S}, 56.09^{\circ} \mathrm{W}\right)$; and Tabatinga, AM $\left(4.25^{\circ} \mathrm{S}, 69.94^{\circ} \mathrm{W}\right)$.

Reserva Biológica do Jaru, RO $\left(10.145^{\circ} \mathrm{S}, 61.908^{\circ} \mathrm{W}\right)$ during the dry biomass burning season of 2007. The diffuse fraction of broadband irradiance reaching the surface as a function of AOD at a $670 \mathrm{~nm}$ wavelength for distinct optical air mass intervals $(m)$, expressed as a ratio of the optical path length relative to the path length at zenith (Fig. 1), was analyzed; a three-degree polynomial fit was proposed as follows:

$D=a \mathrm{AOD}_{670}^{3}+b \mathrm{AOD}_{670}^{2}+c \mathrm{AOD}_{670}+d$.

$D$ represents the diffuse fraction; the values of the fitting parameters $a, b, c$, and $d$ of the function in Eq. (1) are described in Table 1. These fittings were achieved after filtering the data for clouds, which can be present even during the dry season, especially during days with low AOD values. When clouds are present, the diffuse fraction of radiation increases significantly with values as high as a very polluted atmosphere. However, as discussed below, the analysis presented here focuses only on areas and during hours without cloud cover; i.e., the results were obtained by filtering out the points with cloudiness, considering only the model grid boxes where the total column integrated condensed water was equal to zero.
The aim of this work is only to compute the aerosol effect; therefore this filter was essentially used to exclude the effects of clouds in the $\mathrm{CO}_{2}$ fluxes.

\subsection{Model configuration and input data sets}

BRAMS model simulations were conducted for a domain covering the northern part of South America (southwest corner at $18^{\circ} \mathrm{S}, 90^{\circ} \mathrm{W}$ and northeast corner at $15^{\circ} \mathrm{N}, 30^{\circ} \mathrm{W}$ ) using a regular grid with $20 \mathrm{~km}$ of resolution, as illustrated in Fig. 2. JULES was configured with 10 canopy layers. The chosen model domain encompasses the Legal Brazilian Amazon region (LBAR, depicted by the red line in Fig. 2), which is a region of $5016136.3 \mathrm{~km}^{2}$ (59\% of the Brazilian territory). It hosts approximately 24 million inhabitants, which is only around $12 \%$ of the Brazilian population. Brazilian Federal Law No. 5.173 (Art. 2) established the LBAR in 1966 as an administrative unit to promote sustainable development in one of the most, if not the most, resource-rich regions in Brazil. The main tropical biomes in South America, the Amazon rainforest and Cerrado and Pantanal wetlands, are all found in the LBAR. Despite government protection, deforestation activities followed by vegetation fires have led to extensive land use change to pasture and agricultural fields and changes in the atmospheric aerosol load and characteristics. This study aims to analyze the effect of these changes on the atmospheric environment, radiation budget, and forest productivity in this important region.

The NCEP Global Forecast System analysis (http:// rda.ucar.edu/datasets/ds083.2/), with 6-hourly time resolution and $1-1^{\circ}$ of spatial resolution, provided initial and boundary conditions for the time integration of the meteorological fields. Sea surface temperature (SST) was taken from the NOAA Optimum Interpolation (OI) SST product version 2 with $1-1^{\circ}$ of spatial resolution (available at http://www.esrl.noaa.gov/psd/data/gridded/data.noaa. oisst.v2.html; Reynolds et al., 2002). Data from the RADAMBRASIL project (Rossato et al., 1998) were used for the soil type in Brazil, and data from FAO (Zobler, 1999) were used outside Brazil. The model was run with seven soil levels: $0.10,0.35,1.0,2.25,4.25,7.25$, and $12.25 \mathrm{~m}$ below the surface. Soil moisture was initialized with the soil mois- 
ture estimation operational product developed by Gevaerd and Freitas (2006) and available at CPTEC/INPE, and the soil temperature was initialized assuming a vertically homogeneous field defined by the air temperature closest to the surface from the initial atmospheric data. The carbon data assimilation system, Carbon Tracker 2015 (Krol et al., 2005; Peters et al., 2007) with $3-2^{\circ}$ of spatial resolution and 34 vertical levels (available at http://www.esrl.noaa.gov/gmd/ccgg/ carbontracker/), provided $\mathrm{CO}_{2}$ initial and boundary conditions. Initial and boundary conditions for carbon monoxide (CO) were based on optimized fluxes with $1-1^{\circ}$ of spatial resolution as calculated by the $4 \mathrm{D}$-var system using the Infrared Atmospheric Sounding Interferometer (IASI) data taken onboard the Eumetsat Polar System (EPS) Metop-A satellite (Krol et al., 2013).

Biomass burning emissions of trace gases and aerosols were provided by the Brazilian Biomass Burning Emission Model (3BEM; Longo et al., 2010). The 3BEM emissions are based on a database of fire pixel counts and burned area derived from the combination of the following: remote sensing fire products from the Geostationary Operational Environmental Satellite-Wildfire Automated Biomass Burning Algorithm (GOES WF-ABBA product; Prins et al., 1998); the Brazilian National Institute for Space Research (INPE) burning points observed, which are based on the Advanced Very High Resolution Radiometer (AVHRR) aboard the NOAA polar-orbiting satellite series (Setzer and Pereira, 1991); and the Moderate Resolution Imaging Spectroradiometer (MODIS) fire product (Giglio et al., 2003). Fire emissions were split into smoldering and flaming emission contributions, releasing trace gases and aerosol particles in the lowest model layer and in the injection layer, respectively, as determined by the in-line plume rise model (Freitas et al., 2007, 2010).

The land use data set from the United States Geological Survey (USGS) at $1 \mathrm{~km}$ of resolution was merged with a land cover map for the Legal Brazilian Amazon region (PROVEG; Sestini et al., 2003). PROVEG is based on the Landsat Thematic Mapper (TM) images with a spatial resolution of $90-90 \mathrm{~m}$ from the year 2000 and deforestation data from the Amazon Deforestation Monitoring Program (PRODES) for the year 1997. At the $20 \mathrm{~km}$ resolution, each grid box has 400 specifications of vegetation, which were reduced to nine patches of different land cover categories (broadleaf trees, needle leaf trees, C 3 and C4 grasses, shrubs, urban, inland water, soil, and ice), each with its respective occupation fraction. JULES treats each category separately and returns to BRAMS average fluxes weighted by the occupation fraction. The model results are then discussed for the land cover categories present in the considered model domain: broadleaf trees (tropical forest), shrubs (cerrado), and C3 and C4 grasses (pasture). The land use map in the model domain is illustrated in Fig. 2.

The model simulations were initialized on 15 August 2010 at 00:00 UTC and conducted for 45 days. We discarded the first 15 days as spin-up and restricted our analysis to the month of September to avoid model artifacts related to the initial conditions.

A set of three experiments was performed. In the first one (hereafter named NO-AER), the aerosol-radiation interaction was neglected. The direct aerosol effect was taken into account in both the second (hereafter named DIR-AER) and third (hereafter named DIR+DIF) experiments, but only in the latter was the diffuse fraction of radiation passed to JULES. Otherwise it was set to zero. Additionally, a longterm model run (2 years, from January 2010 to December 2011) was carried out only for the DIR+DIF model configuration.

\subsection{Method of analysis of the model results}

Comparing the carbon fluxes from the three model simulations should allow us to assess the aerosol effect on $\mathrm{CO}_{2}$ uptake in Amazonia and the relative roles of surface temperature, the direct aerosol effect, and the increase in the diffuse fraction of PAR due to aerosol scattering. The $\mathrm{CO}_{2}$ fluxes from the model were analyzed as the variation related to the total aerosol effect (both on diffuse radiation and direct radiation):

$\Delta$ Flux $_{\text {tot }}=$ Flux $_{\text {DIR }+ \text { DIF }}-$ Flux $_{\mathrm{NO}-\mathrm{AER}}$.

Only with the direct radiation aerosol effect:

$\Delta$ Flux $_{\text {dir }}=$ Flux $_{\text {DIR-AER }}-$ Flux $_{\text {NO-AER }}$.

And, only with the diffuse radiation aerosol effect:

$\Delta$ Flux $_{\text {diff }}=$ Flux $_{\text {DIR }+ \text { DIF }}-$ Flux $_{\text {DIR }- \text { AER }}$.

We examined the spatial distribution and diurnal cycles of $\mathrm{CO}_{2}$ fluxes related to several surface-atmosphere interaction processes. In addition to GPP, we also looked at the $\mathrm{CO}_{2}$ fluxes associated with plant respiration $\left(R_{\mathrm{P}}\right)$, soil heterotrophic respiration $\left(R_{\mathrm{H}}\right)$, and the net ecosystem exchange (NEE $\left.=R_{\mathrm{P}}+R_{\mathrm{H}}-\mathrm{GPP}\right)$, which is a measurement of the quantity of carbon entering and leaving the ecosystem (negative when the ecosystem is a $\mathrm{CO}_{2}$ sink and positive when it is a $\mathrm{CO}_{2}$ source). The spatial distributions of $\mathrm{CO}_{2}$ fluxes are presented as a monthly mean in $\mu \mathrm{molC} \mathrm{m}{ }^{-2} \mathrm{~s}^{-1}$ for September 2010 at 16:00 UTC, which is around noon local time for most of Amazonia. The diurnal cycles of $\mathrm{CO}_{2}$ fluxes are presented as hourly monthly means in units of $\mu \mathrm{molC} \mathrm{m}{ }^{-2} \mathrm{~s}^{-1}$ for September 2010, considering the model grid cells circumscribed in the LBAR delimited in Fig. 2. The monthly net values of $\mathrm{CO}_{2}$ fluxes in the LBAR are calculated as the integral of the mean diurnal cycles and presented in $\mathrm{TgCmonth}^{-1}$, considering the LBAR area of $\sim 5.2 \times 10^{12} \mathrm{~m}^{2}$, which is the total area of the model cells circumscribed in the LBAR delimited in Fig. 2 multiplied by 30 to get the monthly total.

Because each biome has its own characteristics and responds differently to changes occurring at or under the surface and in the atmosphere, we first examined how each 
biome responds to the presence of biomass burning aerosol both in terms of total irradiance attenuation near the surface and an increase in the diffuse fraction of PAR. We also evaluated the relative contribution of the diffuse to the total (diffuse + direct) aerosol effect on the $\mathrm{CO}_{2}$ fluxes for each biome type. After assessing the specific behavior of each biome, model results for $\mathrm{CO}_{2}$ and energy fluxes from each biome were then averaged and weighted by the biome fraction of each grid to address the heterogeneity of the Amazon region in terms of land cover and local climates.

\subsection{Data sets for model evaluation}

The model results for precipitation and near-surface temperature were contrasted with direct observations and products derived from satellite observations. The aerosol biomass burning spatial distribution from the model was validated with remote sensing products. Additionally, model performance in simulating $\mathrm{CO}$ and $\mathrm{CO}_{2}$ mixing ratios was assessed using measurements of carbon monoxide $(\mathrm{CO})$ and $\mathrm{CO}_{2}$ concentration in air samples collected over the Amazon during 2010 and 2011. The CO concentration varies as a function of fire source, horizontal and vertical transport, and deposition. It was not coupled with the biosphere model. Therefore, the DIR-AER and DIR+DIF scenarios have similar concentration distributions.

Biomass burning mainly releases water vapor and $\mathrm{CO}_{2}$ to the atmosphere but is also a major source of other tracers, such as CO, volatile organic compounds, nitrogen oxides, and organic halogen compounds (Andreae and Merlet, 2001). An enhancement of $\mathrm{CO}$ has been historically observed in Amazonia during the dry season, which is mostly attributed to fire emissions because volatile organic compound (VOC) oxidation is expected to have little seasonality in Amazonia (Holloway et al., 2000; Duncan and Logan, 2008, Andreae et al., 2012). Therefore, the evaluation of CO mixing ratios from the model against observations provides an assessment of model skill to simulate fire emissions and their transport and removal. We also looked into fire activity and used the soil moisture and meteorological variables from the model as indicators of the spatial scale of locations where fires were more likely to occur. The data sets used for model evaluation are described below.

\section{Precipitation}

Monthly mean precipitation over the Amazon region was obtained from the algorithm 3B42 of the Tropical Rainfall Measuring Mission (TRMM) merged high quality (HQ)/infrared (IR) precipitation product at a spatial resolution of $0.25-0.25^{\circ}$ (http://trmm.gsfc.nasa.gov/3b42.html; Kummerow et al., 1998; Kawanishi et al., 2000). TRMM $3 \mathrm{~B} 42$ is derived from retrievals of 3-hourly precipitation amounts from the precipitation radar (PR), TRMM microwave imager (TMI), and visible and infrared scanner
(VIRS) aboard the TRMM satellite merged with rain gauge data from the Climate Anomaly Monitoring System (CAMS) and the Global Precipitation Climatology Project (GPCP). Satellite estimates of precipitation were used for model evaluation due to their more complete spatial and temporal coverage compared to rain gauge data. The latter was also complementarily used to evaluate modeled precipitation and temperature, though not ignoring the low density and heterogeneous distribution of the observational network in the geographical model domain: 72 PCDs (automatic stations installed and maintained by the Brazilian National Institute of Meteorology, INMET) in $5016136.3 \mathrm{~km}^{2}$.

\section{Temperature}

We evaluated the mean diurnal cycle of $2 \mathrm{~m}$ temperature from the model with data from 72 near-surface measurement ground stations in the LBAR; the locations are depicted in Fig. 3a.

\section{Fire activity}

We checked the coherence of soil moisture results from the model with the burning points observed from the Advanced Very High Resolution Radiometer (AVHRR) onboard the NOAA polar-orbiting satellite series. The fire detection used is based on the AVHRR retrieval algorithm from the Brazilian National Institute for Space Research (www.cptec.inpe. br/queimadas).

\section{Biomass burning $\mathrm{CO}$ and $\mathrm{CO}_{2}$}

Model performance in simulating $\mathrm{CO}$ and $\mathrm{CO}_{2}$ mixing ratios was assessed using measurements of carbon monoxide (CO) and $\mathrm{CO}_{2}$ mole fraction ("concentration") in air samples collected over the Amazon during 2010 and 2011. The air samples were collected with portable sampling systems consisting of separate compressor and flask units (Tans et al., 1996) onboard a Cessna 206 aircraft in descending spirals from 4300 to $300 \mathrm{~m}$ over the four Amazon locations indicated in Fig. 2: Santarém, PA $\left(2.43^{\circ} \mathrm{S}, 54.72^{\circ} \mathrm{W}\right)$, Rio Branco, AC $\left(9.97^{\circ} \mathrm{S}, 67.81^{\circ} \mathrm{W}\right)$, Alta Floresta, MT $\left(12.54^{\circ} \mathrm{S}, 55.71^{\circ} \mathrm{W}\right)$, and Tabatinga, AM $\left(4.25^{\circ} \mathrm{S}, 69.94^{\circ} \mathrm{W}\right)$. The air samples collected in Santarém, Rio Branco, and Alta Floresta are characteristic of the moist tropical forest, both primary and secondary, surrounding them. During the dry season, both local (forest) and remote cerrado and pasture fire emissions affect these three sites. The samples collected in Tabatinga, which is further west in a more pristine area of the Amazon forest, respond to the influence of the intact forest landscape upwind. During the dry season, fire emissions influence the atmospheric chemistry in all sites, although the biomass burning impact in Tabatinga is more related to episodic longrange transport events and is not as persistent as the others. The air sampling was always between 12:00 and 14:00 local time and analyzed at the laboratory of the Instituto 

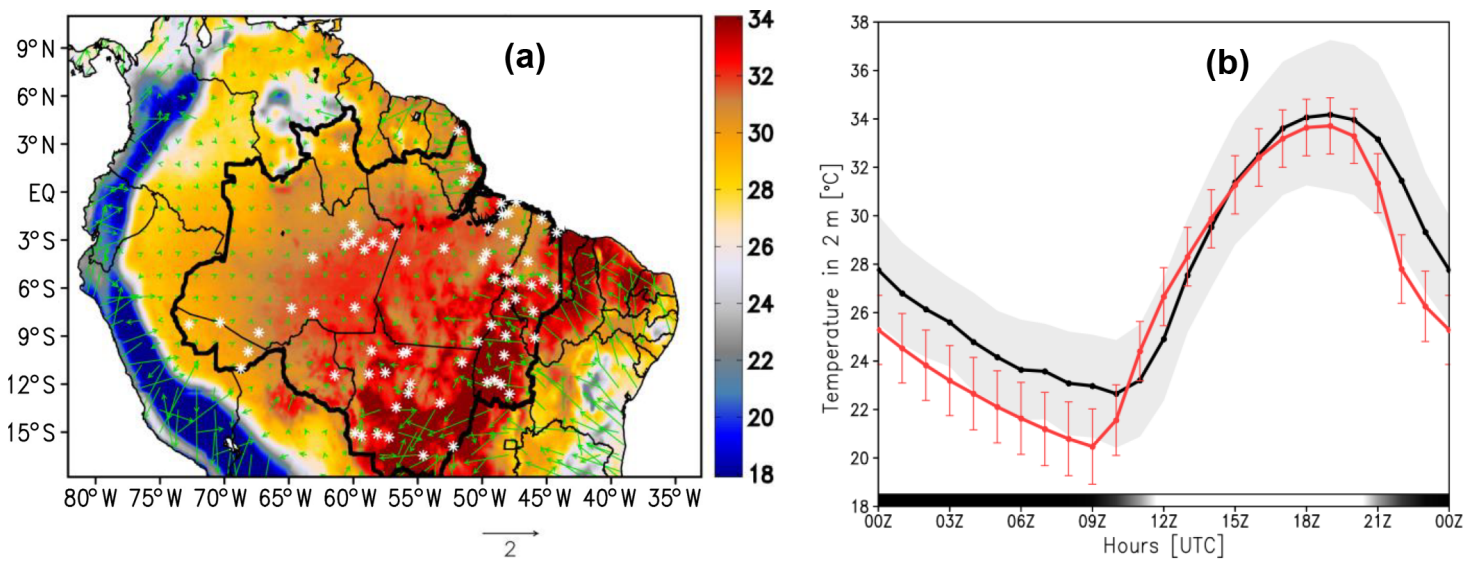

Figure 3. (a) Spatial distribution of mean $2 \mathrm{~m}$ temperature and $10 \mathrm{~m}$ wind field from the model during September 2010 at 16:00 UTC. The LBAR and the locations of 72 near-surface measurement ground stations used to evaluate the model $2 \mathrm{~m}$ temperature are depicted in the map with white asterisks. (b) Mean diurnal cycle of $2 \mathrm{~m}$ temperature $\left({ }^{\circ} \mathrm{C}\right.$ ) observed in the 72 near-surface ground stations (black line) and from the model grid point nearest the respective station (red line). The standard deviation (shaded gray) and the mean observed temperature values were calculated using measurements at the 72 observational stations, while the model standard deviation (red bars) and mean temperature were calculated using the model temperatures at the grid boxes corresponding to the locations of the 72 stations.

de Pesquisas Energéticas e Nucleares (IPEN) in São Paulo, Brazil. Measurement precision of $\mathrm{CO}_{2}$ and $\mathrm{CO}$ is estimated to be around $0.04 \mathrm{ppmv}$ and $0.5 \mathrm{ppbv}$, respectively. For further details regarding air sampling and analytical methods, see Gatti et al. (2010).

We also used $\mathrm{CO}_{2}$ measurements in the Tapajós National Forest near kilometer $67\left(2.85^{\circ} \mathrm{S}, 55.04^{\circ} \mathrm{W}\right)$ of the Santarém-Cuiabá highway, just south of Santarém, for model evaluation. The Tapajós measurements are based on eddy covariance methods using the profile mixing ratio data to estimate the change in vertical average mixing ratio between the ground and flux measurement height to calculate the column average storage of $\mathrm{CO}_{2}$ (Saleska et al., 2003). The $\mathrm{CO}_{2}$ mole fractions were measured at eight levels along the tower $(62.2,50,39.4,28.7,19.6,10.4$, and $0.91 \mathrm{~m})$. Sample air was drawn and analyzed with an infrared gas analyzer (IRGA; LI-6262; Licor, Lincoln, NE). The pressure and temperature of the Licor cells are controlled. The IRGA was automatically zeroed every $2 \mathrm{~h}$ and the Licor profile every $20 \mathrm{~min}$. All Licors are automatically calibrated with span gases every $6 \mathrm{~h}$.

\section{Biomass burning aerosol}

The AOD (aerosol optical depth) product derived from MODIS sensors onboard the Aqua satellite is used to evaluate the simulated biomass burning aerosol plume. In this work, we used the MODIS Level 2.0 Collection 5.1 (051) data and Level 3 atmospheric product denominated MYD08_D3 (mean aerosol optical thickness at $550 \mathrm{~nm}$ ).

\section{Model results and discussion}

\subsection{Meteorology, fire activity, and regional biomass burning plume}

\section{Temperature}

The simulated $2 \mathrm{~m}$ temperature in the central portion of the Amazon Basin during September 2010 peaked around $32^{\circ} \mathrm{C}$ at 16:00 UTC, while the northwest region was slightly cooler, typically ranging from 30 to $28^{\circ} \mathrm{C}$ (Fig. 3a). Going southeast towards the cerrado region, the mean $2 \mathrm{~m}$ temperature reached $35^{\circ} \mathrm{C}$ at $16: 00 \mathrm{UTC}$. The temperature gradient is mostly associated with the gradient of soil moisture and land cover in the region. The evaluation of the mean diurnal cycle of $2 \mathrm{~m}$ temperature from the model against observations using 72 near-surface measurement ground stations in the LBAR during the same period shows that the model results are consistent with observations (Fig. 3.b), though the model mean temperature was typically cooler $\left(\sim 2.5^{\circ} \mathrm{C}\right)$ during the night period and late afternoon hours and was not far from the standard deviation of the observed mean temperature. In addition, the model temperature has a diurnal cycle with a gap of $1 \mathrm{~h}$ earlier than the observation.

\section{Precipitation}

The monthly mean rainfall data from the ground station monitoring network, interpolated to the model grid points (Fig. 4a) and the TRMM rainfall product (Fig. 4b), both reveal a well-defined spatial distribution of the precipitation in the northern region of South America during September 2010. First, in the southeastern Amazon, accumulated rainfall was low, with values typically lower than $50 \mathrm{~mm}$ for this 


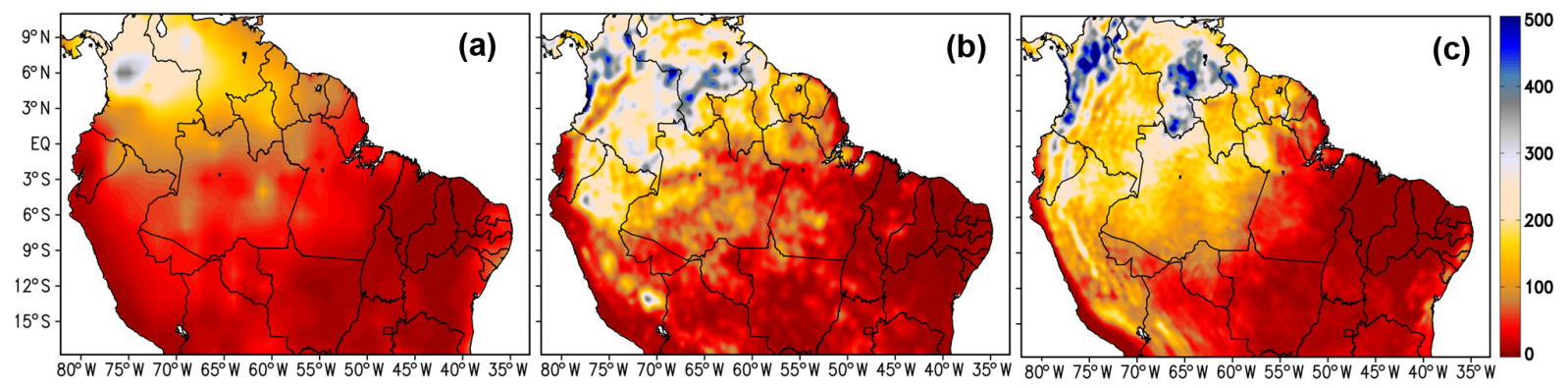

Figure 4. Accumulated precipitation (mm) during September 2010 from the (a) ground station observation network interpolated for the model grid point, (b) TRMM rainfall product, and (c) model results.

month; the northwestern region was wetter, with accumulated values around $200 \mathrm{~mm}$. In addition, there were few areas of high rainfall in the northern part of South America, mainly in the Guiana Highlands, associated with the topographic forcing. The general spatial distribution of model accumulated precipitation (Fig. 4c) compares well with ground observations (Fig. 4a), with an indication that the model overestimated the total precipitation. However, one must take into account that the measurement stations are very scarce in this region, making detailed comparisons difficult. Interpolation in the presence of limited information usually reduces the intensity of precipitation, spreading the value observed around the neighboring grid points without data available. Indeed, the precipitation estimated by TRMM (Fig. 4b) agrees much better with the model results (Fig. 4c).

\section{Soil moisture and fire activity}

As a result of the precipitation distribution, the soils are predominantly wetter in the northwestern part of South America, with simulated volumetric moist content ranging from 0.35 to $0.45 \mathrm{~m}^{3} \mathrm{~m}^{-3}$ for all soil layers (Fig. 5). The high soil moisture of the northwestern Amazonia contrasts with the rest of the region's dryness; the moisture in the top soil layer of the model is below $0.2 \mathrm{~m}^{3} \mathrm{~m}^{-3}$ (Fig. 5a), and only deeper soil layers remain fairly moist $\left(\sim 0.3 \mathrm{~m}^{3} \mathrm{~m}^{-3}\right.$, below $4 \mathrm{~m}$; Fig. $5 \mathrm{c}$ ). Comparing soil moisture in two forest areas with different rainfall regimes (red rectangle, $148 \mathrm{~mm}$ on average and blue rectangle, $34 \mathrm{~mm}$ on average), the area receiving a higher volume of rainfall is about $55 \%$ wetter than the other in the shallow layers but only $12 \%$ in the deeper soil layer. By contrast, comparing areas of forest (blue rectangle) and cerrado (gray rectangle) with similar rainfall regimes (34 $\mathrm{mm})$, the forest region remains considerably wetter $(\sim 15 \%$ in both shallow and deeper layers). According to Köchy and Wilson (2000), high rates of water uptake per unit mass may reflect the high root density of the vegetation. In fact, James et al. (2003) found at a site $20 \mathrm{~km}$ east of Regina, Canada $\left(58.47^{\circ} \mathrm{N}, 104.37^{\circ} \mathrm{W}\right)$ where the ability of grass to reduce soil moisture is nearly 5 times higher than that of woody vegetation expressed on a per-gram basis. For the forest re- gion, the soil moisture values from the model are consistent with the mean value of $0.39 \mathrm{~m}^{3} \mathrm{~m}^{-3}$ measured at $0.2 \mathrm{~m}$ at the Tapajós site (near Santarém; location indicated in Fig. 2) during the dry season (Doughty et al., 2010). Previous measurements at the same site reported soil moisture only slightly higher $\left(\sim 0.44 \mathrm{~m}^{3} \mathrm{~m}^{-3}\right.$ from 0.15 to $\left.0.30 \mathrm{~m}\right)$ and also confirmed the model results for higher moisture in the deeper soil layers $\left(\sim 0.42 \mathrm{~m}^{3} \mathrm{~m}^{-3}\right.$ at $4 \mathrm{~m}$; Bruno et al., 2006).

The period chosen for this study coincided with the peak of the biomass burning season when a total of 439297 fires were detected in the area of the model domain by AVHRRNOAA, which is $42 \%$ of the total number of fires detected by the same sensor during the entire burning season. The spatial distribution of the fires resembles the pattern of precipitation and soil moisture simulated by the model (Fig. 5). Nonetheless, most of the fires were ignited by human activities (Nepstad et al., 1999; Cochrane and Laurance, 2008). Fires occurred mostly in the cerrado, C3 type, and C4 type grasscovered areas, but forest fires with much higher biomass density are typically responsible for the highest amount of biomass burning aerosols and trace gases released into the atmosphere. Figure 6 depicts the spatial distribution of vegetation fires detected by remote sensing over the Amazon and central Brazil during September 2010.

\section{Smoke regional plume, $\mathrm{CO}$, and $\mathrm{CO}_{2}$ mixing ratios}

Model results for the $\mathrm{CO}$ mixing ratio as simulated by the DIR+DIF experiment, which are expected to be the most realistic, were compared with $\mathrm{CO}$ vertical profile measurements from four different sites in Amazonia. The time series of the $\mathrm{CO}$ mixing ratio derived from observations and model results around $2 \mathrm{~km}$ above the ground level in four different locations in Amazonia (Alta Floresta, Santarém, Rio Branco, and Tabatinga) are shown in Fig. 7 (top left). There was an enhancement of $\mathrm{CO}$ from July to October for both years in all four locations. In 2010, the CO mixing ratio values in the PBL during the dry season increased from 100 to $150 \mathrm{ppb}$, which are typical wet season values (Andreae et al., 2012), to up to $500 \mathrm{ppb}$ in both the simulations and observations. The dry season of 2010 had CO mixing ratios about twice 

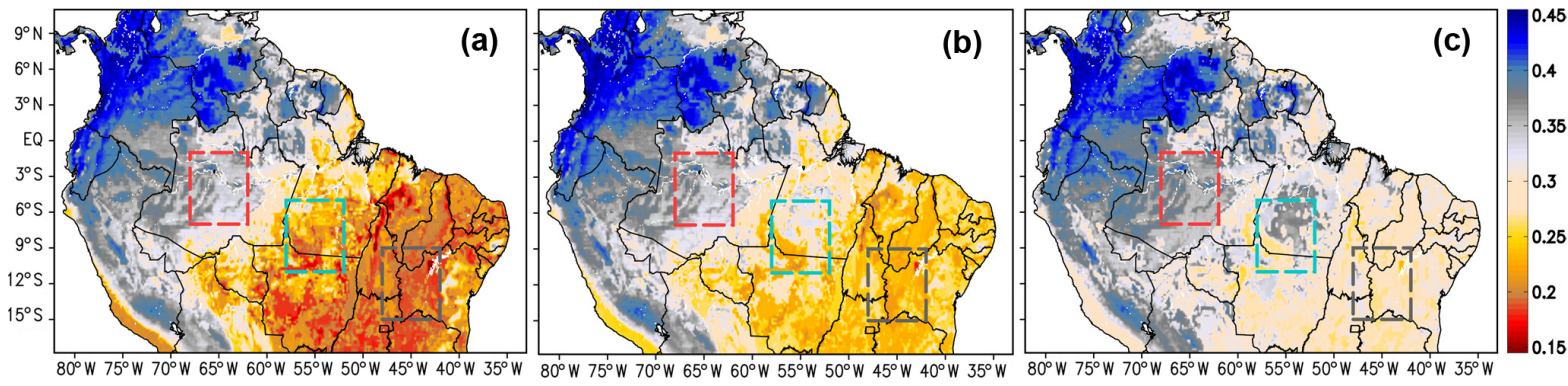

Figure 5. Monthly mean soil moisture $\left(\mathrm{m}^{3} \mathrm{~m}^{-3}\right)$ during September 2010 at three soil levels: (a) $0.35 \mathrm{~m}$, (b) $1.00 \mathrm{~m}$, and (c) $4.25 \mathrm{~m}$. The rectangles depict areas with a predominance of forest and moist soil (red), forest and dry soil (blue), and cerrado with dry soil (gray).

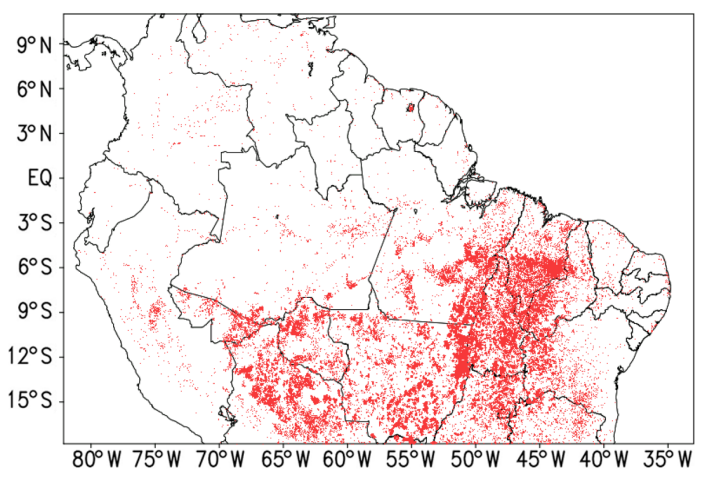

Figure 6. Burning points observed by the AVHRR sensor during September 2010 (source: www.cptec.inpe.br/queimadas).

as high as the same period in 2011; this is consistent with the total number of fires, which approximately doubled, detected by remote sensing during the dry season of these two years (http://www.inpe.br/queimadas/estatisticas.php). Scatterplots of the $\mathrm{CO}$ mixing ratio values from observation and model results for the same four locations separated into several vertical layers are depicted in Fig. 7 (top right). The CO background mixing ratio values for the Tabatinga site are close to the $1: 1$ line, while the biomass-burningaffected values are more scattered. Model results show good agreement with observations but tend to underestimate $\mathrm{CO}$ and $\mathrm{CO}_{2}$ observations, especially at low levels, in locations mainly affected by fire emissions both locally (Alta Floresta, Rio Branco, and Santarém) and by long-range transport (Tabatinga). The black line on each scatterplot in Fig. 7 shows the linear fit and the corresponding R-squared values. The largest underestimation of $\mathrm{CO}$ occurred in Alta Floresta, with a slope of 0.58 , but the biggest dispersion occurred in Santarém, with $R^{2}=0.58$. This pattern is probably related to the $20 \mathrm{~km}$ model resolution not picking up individual biomass burning plumes and fire emission underestimation (Pereira et al., 2016). Previous studies indicated that biomass burning emissions contribute more than $95 \%$ to the variability of $\mathrm{CO}$ over the Amazon and that the emissions used in this study (3BEM; Longo et al., 2010) are about $20 \%$ underestimated (Andreae et al., 2012).

On the other hand, the airborne vertical profiles analyzed in this study and our modeling results indicated a lesser enhancement of $\mathrm{CO}_{2}$ related to fire activity compared to $\mathrm{CO}$. These results are in agreement with previous measurements of fire biomass burning plumes that showed relatively small enhancements of $\mathrm{CO}_{2}$ relative to the background in Amazonia (Andreae et al., 2012). Figure 7 (bottom left) shows the observed (airborne air sampling at around $2 \mathrm{~km}$ above the ground level) and simulated time series of $\mathrm{CO}_{2}$ mixing ratios. The major uncertainty of the $\mathrm{CO}_{2}$ mixing ratios is probably most strongly related to vertical transport, fresh smoke plumes, and uncertainty in the forest NEE. For example, the misplacement of convective systems of few grid cells, which is very acceptable for a low-resolution atmospheric model, can produce huge variations in the $\mathrm{CO}_{2}$ values near the surface. In addition, the timing of the convection in tropical regions is a well-known limitation of atmospheric models in general. Nonetheless, the $\mathrm{CO}_{2}$ scatterplots (Fig. 7, bottom right) evidenced much higher variability in both observed and modeled values compared to $\mathrm{CO}$ and a poorer model representation value close to the ground compared to the upper levels. The low-level behavior is likely to be associated with local convective processes but could also have a minor contribution from fresh biomass burning plumes both venting $\mathrm{CO}_{2}$ and locally changing the diffuse fraction of solar radiation. By contrast, the model tends to better represent the upper levels in terms of observed $\mathrm{CO}_{2}$, which is due to the fact that air circulation is more intense and mainly controlled by the Carbon Tracker boundary conditions, and the fire emission contribution becomes even less significant. However, the model is not sensitive to the $\mathrm{CO}_{2}$ concentration within the given range, and therefore the model problems in reproducing point observations should not have a major effect on the final results.

\section{Biomass burning regional plume AOD}

In Fig. 8, we show the mean regional biomass burning plume for September 2010 through the monthly mean AOD at a 

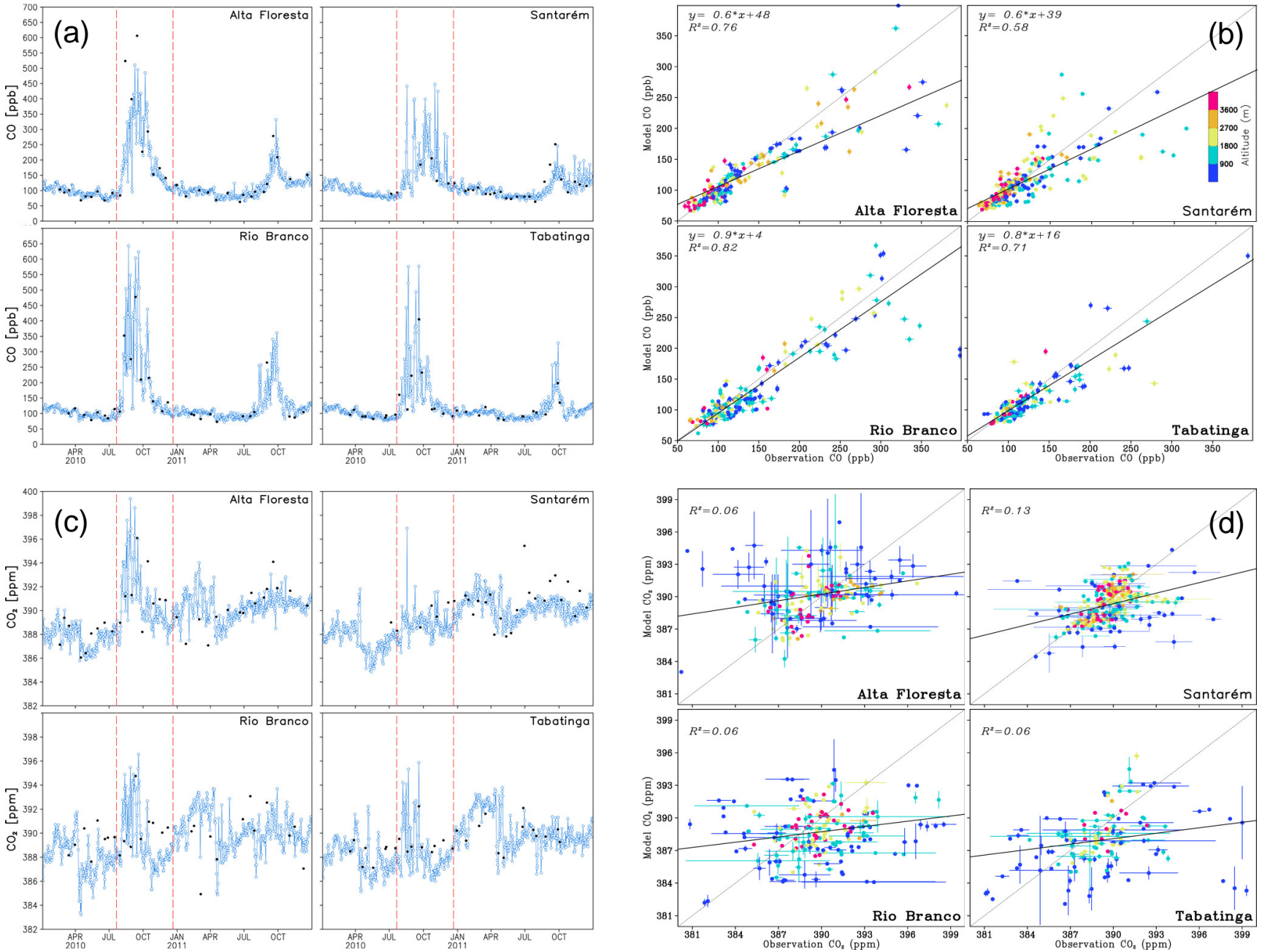

Figure 7. Time series (a, c) and scatterplots (b, d) of $\mathrm{CO}(\mathrm{ppbv} ; \mathbf{a}, \mathbf{b})$ and $\mathrm{CO}_{2}$ (ppbv; $\left.\mathbf{c}, \mathbf{d}\right)$ airborne measured (black dots) and simulated (DIR+DIF experiment, blue dots and line) at Alta Floresta, Santarém, Rio Branco, and Tabatinga (indicated on each plot) at about $2 \mathrm{~km}$ above the ground level from April 2010 to October 2011. On the time series, the red dashed lines indicate the fire season of 2010. On the scatterplots, the colors scale depicts the vertical layers: <900 m (purple), 900-1800 m (blue), 1800-2700 (green), 2700-3600 (orange), and $>3600 \mathrm{~m}$ (pink), and the error bars refer to the standard deviation of the mean values. The locations of the measurement sites are indicated in Fig. 2.
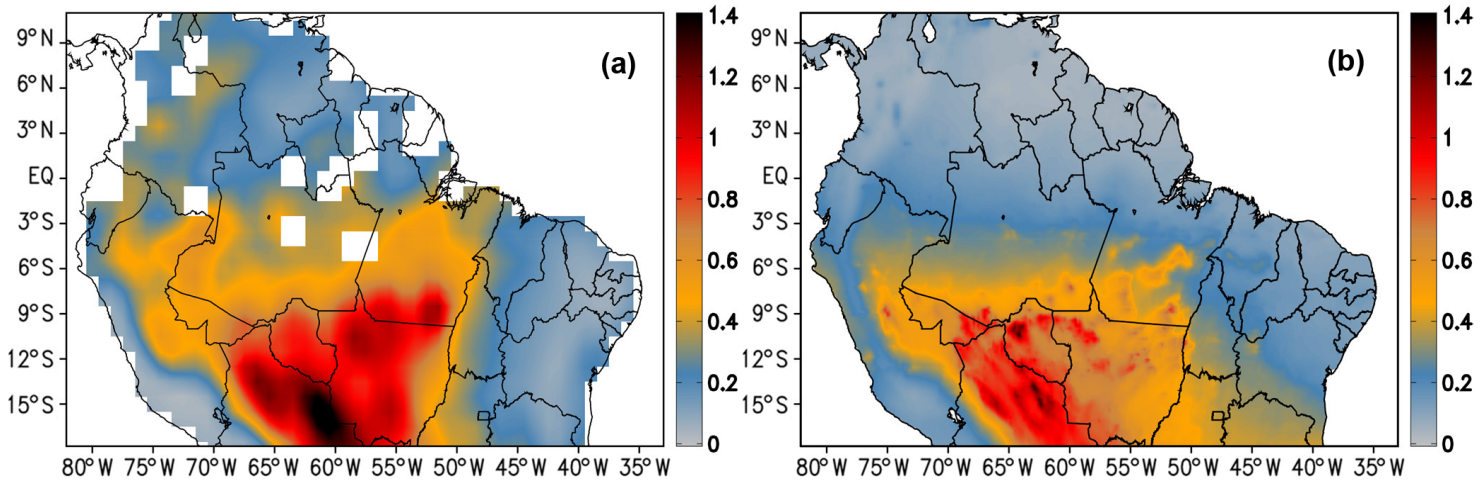

Figure 8. Monthly mean AOD at a $550 \mathrm{~nm}$ wavelength for September 2010 from the (a) MODIS Aqua retrieval and (b) from the model as simulated in the DIR+DIF experiment. 
$550 \mathrm{~nm}$ wavelength from both the MODIS Aqua retrieval (Fig. 8a) and the DIR+DIF model simulation (Fig. 8b). A substantial portion of central Brazil, neighboring countries, and the southern Amazon Basin were covered by smoke with a resulting monthly mean AOD higher than 0.5 , which is 3 to 5 times larger than the typical values of clean conditions. Moreover, there were also large sub-areas with a monthly mean AOD higher than 1, indicating persistent and high loading of smoke particles. The model results fairly reproduced the spatial distribution of the regional smoke plume from MODIS retrievals. A scatterplot of AOD values from the model and MODIS retrieval (Fig. S5 in the Supplement) presents a slope of 0.71 (with $R^{2}=0.73$ ). Conversely, MODIS retrievals tend to overestimate AOD in relation to the AERONET retrievals in Amazonia, especially for high aerosol loadings (Hoelzemann et al., 2009). Analysis of model results versus AERONET retrieval in some sites in southern Amazonia (not shown) confirmed that the order of magnitude of the model underestimation is about the same $20 \%$ as previously estimated.

\section{Site-level plant-atmosphere $\mathrm{CO}_{2}$ exchange}

Figure 9a shows the mean diurnal cycle of the $\mathrm{CO}_{2}$ mixing ratio in the first model layer of the three experiments together with the mean diurnal cycle of the $\mathrm{CO}_{2}$ mixing ratio just above the canopy of the Tapajós forest (near Santarém; location indicated in Fig. 2) from measurements during September 2010. In Tapajós, both observation and model results present a nighttime increase in $\mathrm{CO}_{2}$ due to plant respiration, peaking shortly after sunrise, and a daytime decrease due to photosynthetic processes, with the lowest values before sunset. Despite the model difficulties in simulating the $\mathrm{CO}_{2}$ mixing ratio near surface, on average, the discrepancies with observations were only about 0.9 and $1.4 \%$ for the maximum and minimum values, respectively, with the model values lower than the observation values during the peak hour and vice versa when the photosynthetic process dominates. The model amplitude of the $\mathrm{CO}_{2}$ cycle is lower than that observed, though the model cycle is still within the standard deviation of the mean observed diurnal cycle. Model results without including aerosol effects (NO-AER) and with the inclusion of the direct aerosol effect only (DIR-AER) produce a very similar $\mathrm{CO}_{2}$ diurnal cycle. However, the inclusion of the diffuse radiation effects due to biomass burning aerosols reduces the values of the $\mathrm{CO}_{2}$ mixing ratio and brings model results much closer to observation, especially during the day, even though the mean AOD modeled in Tapajós was very low compared to the area mostly affected by biomass burning and even underestimated by the model. A curious fact is that at night the difference between NO-AER and DIR+DIF is greater than in the daytime period. One possible explanation for this is the influence of the neighborhood. Note in Fig. S6 that the average wind at 00:00 UTC is from the east, a forest region, and has differences between aerosol and non- aerosol simulations. However, the wind at 10:00 UTC is from the northeast and crosses the river, where the influence of the aerosol in the carbon fluxes is low. Considering the whole LBAR, which includes the region with the highest aerosol load, the inclusion of the aerosol effect on $\mathrm{CO}_{2}$, especially the effect of the diffuse radiation, reduced the $\mathrm{CO}_{2}$ mixing ratio by about $10 \mathrm{ppmv}$ in the $\mathrm{CO}_{2}$ mixing ratio all day long (Fig. 9b). The shift of the diurnal cycle of the $\mathrm{CO}_{2}$ mixing ratio from the model relative to the observation in Tapajós is likely to be related to the AOD underestimation.

In the next section, we will present the model results for energy and carbon fluxes and explore the role played by biomass burning aerosol in the carbon cycle in Amazonia.

\subsection{JULES sensitivity test}

We performed sensitivity tests to assess the JULES response to several atmospheric variables. We ran JULES offline (version 3.0) for September 2010 using as input BRAMS results for the NO-AER experiment considering the nearest grid box to the tower at kilometer 67 . Figure S1 shows monthly variation in downwelling shortwave (RSHORT) and longwave irradiance (Rlong), air temperature near the surface, and specific humidity near the surface, all used as input for the sensitivity test. The soil carbon in this grid cell is $10 \mathrm{kgCm}^{-2}$ during the entire month. In addition to using the BRAMS model results for each parameter, we varied each parameter by reducing and increasing its original value to cover the standard deviation of the monthly mean. We also varied the diffuse fraction of the shortwave radiation, which was originally zero (NO-AER scenario), from 0 to 0.8 of the total radiation. Therefore, we ran 567 simulations for the month of September 2010. For each simulation, we calculated the monthly mean fluxes. Figures S2, S3, and S4 show the results for these sensitivity tests. JULES results for soil respiration, and consequently NEE, are quite sensitive to the prescribed soil carbon content (Fig. S2). In addition, the GPP increases with the increase in soil moisture for all biomes (Fig. S3). However, $R_{\mathrm{H}}$ and $R_{\mathrm{P}}$ also increase with soil moisture (Fig. S3a and S3m). Therefore, for the forest and cerrado biomes, the NEE decreases until a certain value and then increases again with increasing soil moisture (Fig. S3s). In summary, the sensitivity analyses show that (i) for a $7 \%$ decrease in shortwave radiation there are minimal changes in GPP (Fig. S4a); (ii) a change in temperature of $1{ }^{\circ} \mathrm{C}$ (from current midday conditions) did not imply major changes in the simulated GPP (Fig. S4b); and (iii) a $40 \%$ increase in the diffuse fraction of shortwave radiation increased the GPP by $39,71,4$, and $72 \%$ in forest, C3 grasses, C4 grasses, and cerrado (shrubs) vegetation, respectively (Fig. S4c). 

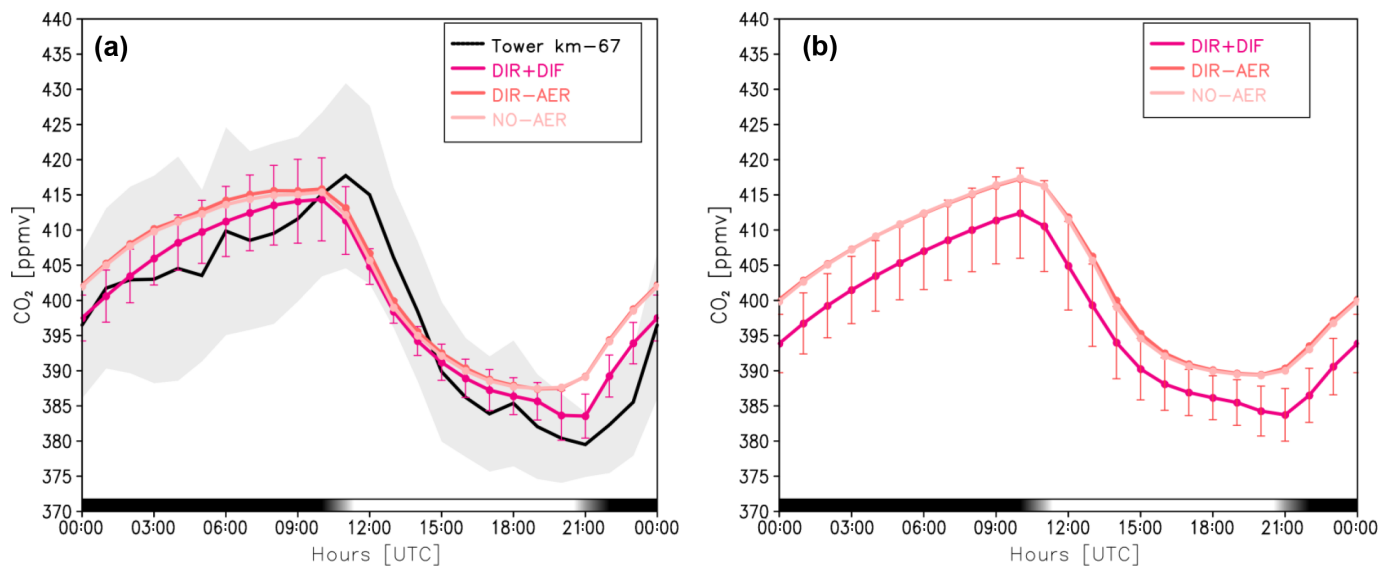

Figure 9. (a) Mean diurnal cycle of the $\mathrm{CO}_{2}$ (ppmv) mixing ratio (black line) during September 2010 in Tapajós forest tower at $39.6 \mathrm{~m}$ $\left(2.85^{\circ} \mathrm{S}, 55.04^{\circ} \mathrm{W}\right.$; slightly southward of Santarém; location indicated in Fig. 2). The gray shaded area indicates the standard deviation of mean values observed. (b) Mean diurnal cycle of the $\mathrm{CO}_{2}$ (ppmv) mixing ratio from the model during the same period in the LBAR (red line in Fig. 2). In both plots, model results are at the 39.3 m model level for the three simulations NO-AER (light pink), DIR-AER (pink), and DIR+DIF (red). The red error bars on the model curves refer to the standard deviation of the mean model values.
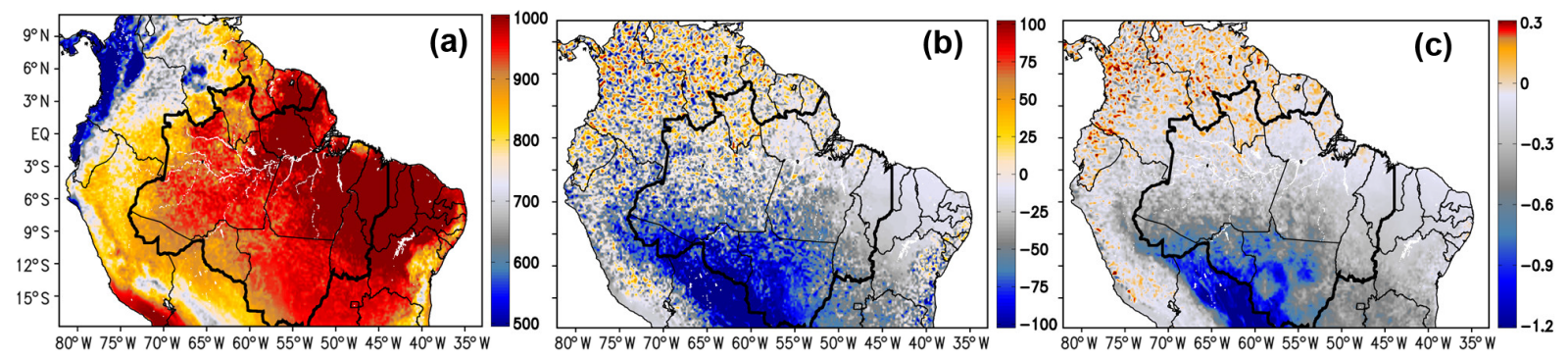

Figure 10. (a) Mean downwelling shortwave irradiance at the surface $\left(\mathrm{Wm}^{-2}\right)$ at 16:00 UTC (which is around midday in most of Amazonia) for September 2010 from the DIR+DIF experiment; (b) the difference in the mean downwelling shortwave irradiance at the surface $\left(\mathrm{Wm}^{-2}\right.$ ) during the same time period as simulated in DIR+DIF and NO-AER; and (c) the difference in the $2 \mathrm{~m}$ temperature $\left({ }^{\circ} \mathrm{C}\right)$ during the same time period as simulated in DIR+DIF and NO-AER. The darker black contour line on the maps delimits the LBAR.

\subsection{Impacts of biomass burning aerosol on energy and carbon fluxes}

\section{Incoming radiation}

The modeled mean downwelling shortwave irradiance at the surface (RSHORT) at 16:00 UTC during September 2010 from the DIR-AER experiment ranged from $900 \mathrm{Wm}^{-2}$ in the southwestern Amazon to $1000 \mathrm{Wm}^{-2}$ in the northeastern portion (Fig. 10a), with the biomass burning aerosol direct impact $\left(\triangle \mathrm{RSHORT}=\mathrm{RSHORT}_{\mathrm{DIR}-\mathrm{AER}}-\right.$ $\mathrm{RSHORT}_{\mathrm{NO}-\mathrm{AER}}$ ) reaching $-100 \mathrm{Wm}^{-2}$ in biomass burning areas (AOD $>0.5$; Fig. 10b). As a consequence of the biomass burning aerosol direct effect, the $2 \mathrm{~m}$ temperature decreased by $1.2^{\circ} \mathrm{C}$ on average in the biomass burning areas around midday $\left(\Delta \mathrm{Temp}=\mathrm{Temp}_{\mathrm{DIR}-\mathrm{AER}}-\mathrm{Temp}_{\mathrm{NO}-\mathrm{AER}}\right.$, Fig. 10c). The noise in the northwestern region for both RSHORT and temperature differences within the two simulations is related to expected nonlinear aerosol perturbations on cloud distribution. These results are consistent with previ- ous modeling studies (Rosário et al., 2013) and with estimations based on AERONET measurements (Procópio et al., 2004). Additionally, observations in Tapajós during the dry season indicate an average reduction of 80 and $123 \mathrm{Wm}^{-2}$ for $\mathrm{AOD}>0.5$ and $\mathrm{AOD}>0.7$, which corresponded to a decrease in the mean temperature of 0.26 and $0.41^{\circ} \mathrm{C}$, respectively.

The presence of biomass burning aerosol in the atmosphere also impacts the flux of PAR in Amazonia during the dry season. Monthly mean PAR $\left(\mu \mathrm{mol} \mathrm{m} \mathrm{m}^{-2} \mathrm{~s}^{-1}\right)$ at 16:00 UTC, which is around midday in most of Amazonia, as simulated by the DIR+DIF model experiment for September 2010 is depicted in Fig. 11a. The modeled PAR monthly mean values at 16:00 UTC ranged between 900 and $1000 \mu \mathrm{mol} \mathrm{m} \mathrm{m}^{-2} \mathrm{~s}^{-1}$ from southwest to northeast in the LBAR. The presence of biomass burning aerosol increases the diffuse fraction of radiation by up to $40 \%$ in the biomass burning areas (Fig. 11b). Figure 12a shows the diffuse PAR as a function of AOD. 

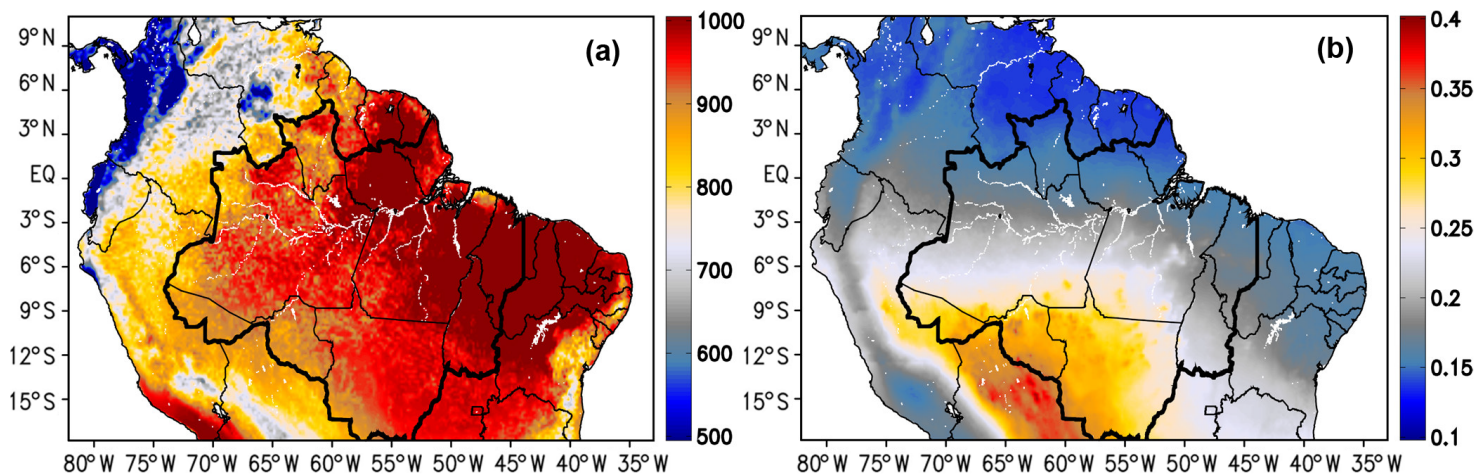

Figure 11. (a) Mean PAR $\left(\mu\right.$ molm ${ }^{-2} \mathrm{~s}^{-1}$ ) at 16:00 UTC for September 2010 from the DIR+DIF experiment and (b) the mean diffuse fraction of solar radiation at 16:00 UTC for September 2010 as simulated by DIR+DIF. The darker black contour line on the maps delimits the LBAR.
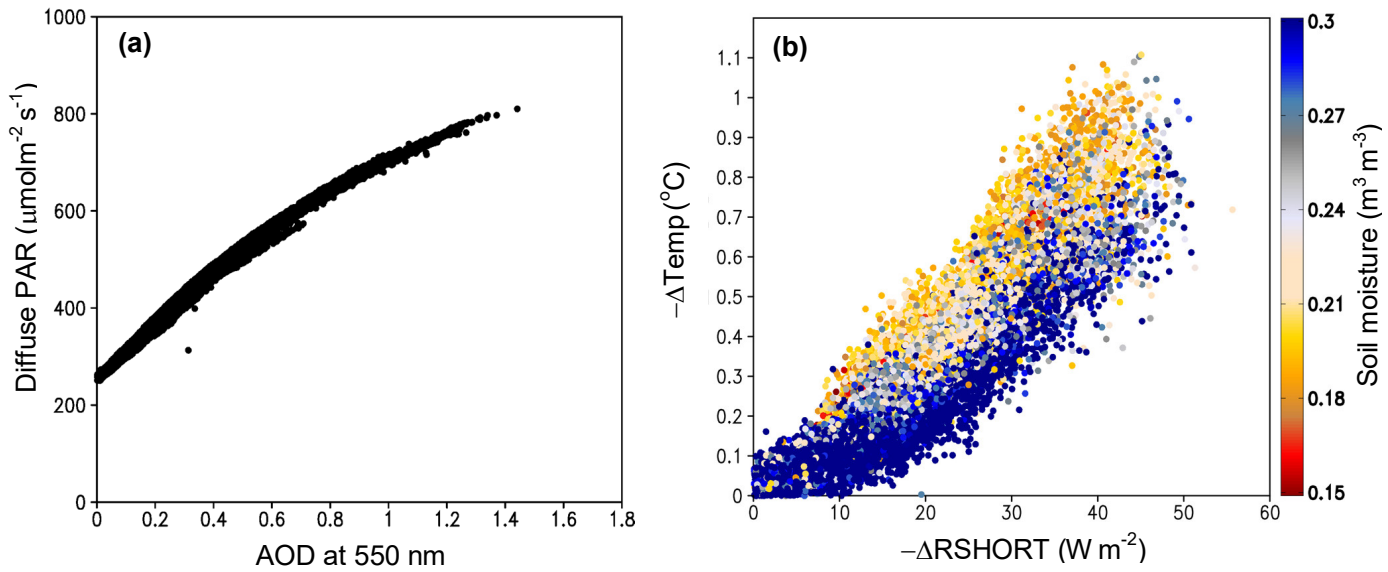

Figure 12. (a) The diffuse PAR radiance $\left(\mu \mathrm{molm} \mathrm{m}^{-2} \mathrm{~s}^{-1}\right.$ ) versus AOD at $550 \mathrm{~nm}$ as simulated in the DIR+DIF experiment at 16:00 UTC during September 2010 (temporal) in the LBAR (spatial). (b) The decrease in $2 \mathrm{~m}$ temperature versus the decrease in downwelling shortwave irradiance $\left(\mathrm{Wm}^{-2}\right)$ as simulated in the AER-DIR and NO-AER experiments at 16:00 UTC during September 2010 in the LBAR. The color scale refers to soil moisture $\left(\mathrm{m}^{3} \mathrm{~m}^{-3}\right)$ at $0.35 \mathrm{~m}$.

Decreases in surface temperature due to the direct effect of aerosol are also influenced by the balance between latent and sensible heat fluxes or, ultimately, on soil moisture. The difference in $2 \mathrm{~m}$ temperature $(\Delta$ Temp) and shortwave irradiance $(\triangle \mathrm{RSHORT})$ is, as expected, highly correlated, though with a large band of $\Delta$ Temp for the same value of $\Delta$ RSHORT (Fig. 12b). The $\Delta$ Temp bandwidth increases almost linearly with the $\triangle$ RSHORT, with the values corresponding to higher soil moisture populating the lower part of the curve (Fig. 12b). This means that for regions with the same AOD, the ones with drier soil will suffer higher surface cooling.

\section{Carbon fluxes for the vegetation types in Amazonia}

Spatial fields for simulated GPP across the northern part of South America are presented in Fig. 13a for September 2010 at 16:00 UTC for forest, C3G, C4G, and shrubs in rows 1-4, respectively. Over forest, simulated GPP ranges from 20 to $25 \mu \mathrm{molC} \mathrm{m}{ }^{-2} \mathrm{~s}^{-1}$, while over the regions occupied by cer- rado, pastures, and tinges of forest there was much higher variability, with GPP widely varying from below 5 to above $20 \mu \mathrm{molC} \mathrm{m}^{-2} \mathrm{~s}^{-1}$. In column (b) of Fig. 13, we show the difference between monthly mean GPP as simulated for the DIR+DIF and NO-AER experiments, i.e., the relative impact of the total effect of aerosols on simulated GPP for the four studied biome types: forest (b1), C3G (b2), C4G (b3), and cerrado (b4). In column (c), we show the difference between the monthly mean GPP of the simulation without the aerosol effect on the diffuse radiation (DIR-AER) and the simulation without any aerosol effects (NO-AER); i.e., we evaluate the relative impact on the direct solar radiation effect.

In Fig. 14a, one can note that the mean solar irradiance that reaches the Amazon region during September promotes a high GPP for the $\mathrm{C} 4$ plants even into the local afternoon when $\mathrm{C} 3$ plants close their stomata to reduce water loss. Thus, typically, the GPPs of the $\mathrm{C} 4$ plants are highly correlated with the amount of irradiance received. Therefore their GPP resembles the same diurnal cycle shape of the ir- 

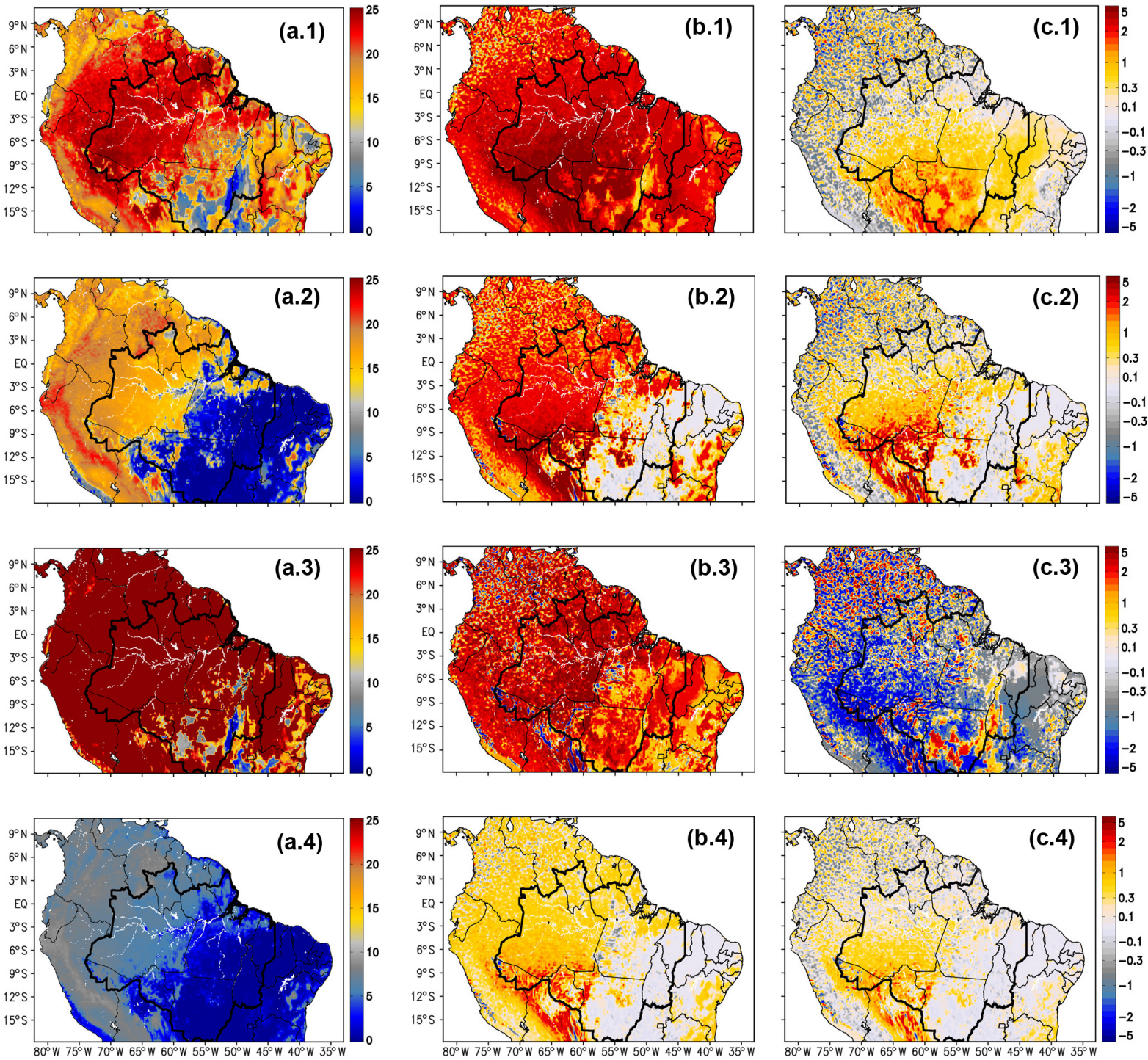

Figure 13. Mean GPP $\left(\mu \mathrm{molCm}{ }^{-2} \mathrm{~s}^{-1}\right.$ ) for September 2010 at 16:00 UTC as simulated in DIR+DIF (column a), the difference in the monthly mean GPP $\left(\mu \mathrm{molCm}{ }^{-2} \mathrm{~s}^{-1}\right)$ as simulated in DIR+DIF and NO-AER (column b), and DIR-AER and NO-AER (column c). The first to the fourth rows present the results for the biomes of forest, $\mathrm{C} 3 \mathrm{G}, \mathrm{C} 4 \mathrm{G}$, and shrubs, respectively. The darker black contour line on the maps delimits the LBAR.

Table 2. Monthly mean values of net GPP, $\Delta \mathrm{GPP}_{\text {tot }}$, and $\triangle \mathrm{GPP}_{\mathrm{dir}}$ in the LBAR during September 2010 for the three simulations and different biomes.

\begin{tabular}{lr|rr|rr}
\hline Biome & $\begin{array}{r}\mathrm{GPP}_{\mathrm{DIR}+\mathrm{DIF}} \\
{\left[\mathrm{TgCmonth}^{-1}\right]}\end{array}$ & $\begin{array}{r}\Delta \mathrm{GPP}_{\text {tot }} \\
{\left[\mathrm{TgCmonth}^{-1}\right]}\end{array}$ & $\begin{array}{r}\Delta \%] \\
{\left[\mathrm{GPP}_{\text {dir }}\right.}\end{array}$ \\
\hline Forest & 1206 & 293 & 32 & 8 & 1 \\
C3G & 850 & 195 & 30 & 24 & 3 \\
C4G & 2431 & 200 & 9 & -69 & -3 \\
Cerrado & 359 & 59 & 20 & 12 & 3 \\
\hline
\end{tabular}

radiance. By contrast, the other vegetation types suffer, to a lesser or greater extent, a decrease in carbon assimilation during the period of maximum irradiance, thereby re- shaping their GPP diurnal cycle. Still in Fig. 14a, the net increase in GPP due to biomass burning aerosol over forest $\left(\Delta \mathrm{GPP}_{\text {tot }}\right.$; difference between the curves in the red and 
Table 3. NEE measurements during the dry season in several locations in the Amazon region, Brazil. The mean values and standard deviations of NEE from the modeling results from the DIR+DIF experiment (September 2010) are also presented in the last column.

\begin{tabular}{|c|c|c|c|c|c|c|c|c|}
\hline & \multirow[b]{2}{*}{ Biome } & \multirow[b]{2}{*}{$\begin{array}{l}\text { Data } \\
\text { collection }\end{array}$} & \multicolumn{3}{|c|}{ NEE from flux measurements } & \multicolumn{3}{|c|}{ NEE from the model (Sept 2010) } \\
\hline & & & Daily total & Nighttime & $\begin{array}{r}\text { Daytime } \\
\text { peak }\end{array}$ & Daily total & Nighttime & $\begin{array}{r}\text { Daytime } \\
\text { peak }\end{array}$ \\
\hline Location & Type & Period & $\mathrm{molCm}^{-2}$ day $^{-1}$ & $\mu \mathrm{molCm}^{-2} \mathrm{~s}^{-1}$ & $\mu \mathrm{molCm}^{-2} \mathrm{~s}^{-1}$ & $\mathrm{molCm}^{-2}$ day $^{-1}$ & $\mu \mathrm{molCm}^{-2} \mathrm{~s}^{-1}$ & $\mu \mathrm{molCm}^{-2} \mathrm{~s}^{-1}$ \\
\hline $\begin{array}{l}\text { Jaru }^{\mathrm{a}} \\
\text { Jaru }^{\mathrm{b}}\end{array}$ & Forest & $\begin{array}{l}\text { Sept } 1992 \\
\text { Dry season 1999-2002 }\end{array}$ & $\begin{array}{l}-0.090 \\
-0.069\end{array}$ & $\begin{array}{r}- \\
+7.1\end{array}$ & $\begin{array}{r}- \\
-17.5\end{array}$ & $-0.065 \pm 0.002$ & $+5.2 \pm 0.8$ & $-11.9 \pm 2.4$ \\
\hline $\mathrm{FNS}^{\mathrm{c}}$ & Pasture & Dry season $1999-2002$ & -0.12 & +3.0 & -13.2 & $-0.14^{\mathrm{g}} \pm 0.1$ & $+3.3 \pm 0.8$ & $-13.1 \pm 5.4$ \\
\hline Tapajós $^{\mathrm{d}}$ & Forest & $\begin{array}{l}\text { Sept } 2002 \\
\text { Sept } 2003 \\
\text { Sept } 2004 \\
\text { Sept } 2005\end{array}$ & $\begin{array}{l}+0.017 \\
+0.026 \\
-0.017 \\
-0.069\end{array}$ & $\begin{array}{l}- \\
- \\
- \\
-\end{array}$ & $\begin{array}{l} \\
- \\
- \\
-\end{array}$ & $-0.032 \pm 0.039$ & $+5.6 \pm 0.9$ & $-11.9 \pm 0.6$ \\
\hline Sinop $^{\mathrm{e}}$ & Forest & $\begin{array}{l}\text { Dry season } 2005-2006 \\
\text { Dry season } 2006-2007 \\
\text { Dry season } 2007-2008\end{array}$ & $\begin{array}{l}+0.008 \pm 0.029 \\
-0.013 \pm 0.024 \\
-0.041 \pm 0.022\end{array}$ & $\begin{array}{l}+5.2 \pm 0.4 \\
+5.5 \pm 0.4 \\
+5.6 \pm 0.3\end{array}$ & $\begin{array}{l}- \\
- \\
-\end{array}$ & $-0.23 \pm 0.006$ & $+3.0 \pm 0.3$ & $-14.4 \pm 1.0$ \\
\hline Cuieiras $^{\mathrm{f}}$ & Forest & Dry season 1999-2009 & - & $\sim+4.0$ & -20.0 & $+0.037 \pm 0.015$ & $+6.8 \pm 1.0$ & $-11.7 \pm 1.4$ \\
\hline
\end{tabular}

green filled squares) is $3.8 \mu \mathrm{molC} \mathrm{m}{ }^{-2} \mathrm{~s}^{-1}$, with the majority $\left(\%\right.$ Flux $\left._{\text {diff }} \cong 94 \%\right)$ of the impact related to the increase in the diffuse fraction of solar radiation. The reduction in direct solar radiation by biomass burning aerosols increases forest GPP only up to $0.2 \mu \mathrm{molC} \mathrm{m}{ }^{-2} \mathrm{~s}^{-1}\left(\Delta \mathrm{GPP}_{\mathrm{dir}}\right)$, which is associated with the cooling of the leaves. Over cerrado areas, the increase in GPP was up to 0.9 and $0.1 \mu \mathrm{molC} \mathrm{m}^{-2} \mathrm{~s}^{-1}$ due to the aerosol effect on the diffuse fraction of radiation $\left(\Delta \mathrm{GPP}_{\mathrm{diff}}\right)$ and the direct radiation $\left(\Delta \mathrm{GPP}_{\mathrm{dir}}\right)$, respectively, with the aerosol direct radiative effect much lower than the diffuse radiation effect because the GPP of the cerrado is also severely limited by the excess of irradiance. In the case of the $\mathrm{C} 4$ grass type, which was not limited by irradiance, the direct radiative aerosol effect induced a reduction in the GPP $\left(-0.7 \mu \mathrm{molC} \mathrm{m}{ }^{-2} \mathrm{~s}^{-1}\right)$, but the increase in the diffuse fraction of radiation more than compensates for the reduction in GPP due the irradiance attenuation of the direct effect. When including both direct and diffuse radiation effects, the GPP increases from 43 to $47 \mu \mathrm{molC} \mathrm{m}^{-2} \mathrm{~s}^{-1}$. Table 2 summarizes the integrated values of GPP for each biome in the LBAR during September 2010 and the variation related to the total aerosol effect (both on diffuse radiation and direct radiation; $\triangle \mathrm{GPP}_{\text {tot }}$ ) and only with the direct aerosol effect $\left(\triangle \mathrm{GPP}_{\mathrm{dir}}\right)$. According to the model results, the net GPP of the forest biome in the LBAR was $1206 \mathrm{Tg}$ C during September 2010. The presence of biomass burning aerosol was responsible for an increase of about $32 \%$ of the GPP over the forest, mainly associated with the impact of the aerosol on the diffuse radiation. For the cerrado and $\mathrm{C} 3$ grass, the net GPP was 359 and $850 \mathrm{Tg} \mathrm{C}$ in the same region during the same period, with the biomass burning aerosol acting to increase the GPP by about 20 and $30 \%$, respectively. We estimated an average increase of $27 \%$ in GPP for September 2010 in the LBAR associated with the aerosol effect in Amazonia (Table 4). However, Rap et al. (2015), using the JULES model forced with aerosol field from another model, estimated an average increase in GPP of only $2.8 \%$ for August considering the period 1998-2007. Also, our estimate of net primary production $\left(\mathrm{NPP}=\mathrm{GPP}-R_{\mathrm{P}}\right)$ for the DIR+DIF simulation was $553 \mathrm{TgC}$ month $^{-1}$ (1113$560)$ and $363 \mathrm{TgC}$ month $^{-1}((1113-240)-(560-50))$ for NOAER. Therefore, we estimate an increase of $52 \%$ in NPP for September 2010 due to the aerosol in the LBAR, while Rap et al. (2015) estimated a increase in NPP of only $5.4 \%$ for August. Our results for the aerosol impact over Amazonia is higher than the Rap et al. (2015) estimation. However, one must keep in mind that the Rap et al. estimation was based on 9 years (1998-2007) and for a month (August) that typically has much lower aerosol loading than September. Our work was based on September, the peak for the biomass burning season, and 2010, a drier and smokier year. The diurnal cycle of plant respiration for each biome is shown in Fig. 14b for the three model runs. As expected, higher GPP leads to higher plant respiration. Plant respiration peaks are 7.5, 2, 4.6, and $14 \mu \mathrm{molC} \mathrm{m}^{-2} \mathrm{~s}^{-1}$ for forest, cerrado, $\mathrm{C} 3$ grass types, and $\mathrm{C} 4$ grass types, respectively, with the aerosol impact more pronounced for forest and $\mathrm{C} 4$ biomes. The mean soil respiration found in the LBAR is $2.78 \mu \mathrm{molC} \mathrm{m}^{-2} \mathrm{~s}^{-1}$, with a relatively mild diurnal cycle that basically depends on soil temperature and hence has lower values in the morning and a tendency to increase slightly in the afternoon. However, soil respiration is highly variable in the LBAR, depending on the amount of carbon in the soil, which is as low as $0.13 \mu \mathrm{molC} \mathrm{m}{ }^{-2} \mathrm{~s}^{-1}$ in the cerrado and grass plot areas and ranges between 2 and $8 \mu \mathrm{molC} \mathrm{m}^{-2} \mathrm{~s}^{-1}$ in forest areas. Regarding NEE, model results show that the forest biome released around $+5 \mu \mathrm{molC}^{-2} \mathrm{~s}^{-1}$ during the night and early morning, and then when GPP 
compensates for the respiration, the net uptake goes as low as $-11 \mu \mathrm{molC} \mathrm{m} \mathrm{m}^{-2} \mathrm{~s}^{-1}$. The net effect is an uptake of approximately $0.015,0.565$, and $0.060 \mathrm{molC} \mathrm{m}^{-2}$ day $^{-1}$ for the $\mathrm{C} 3$ grass, $\mathrm{C} 4$ grass, and forest biomes, respectively, and a release of $0.126 \mathrm{molC} \mathrm{m}^{-2} \mathrm{day}^{-1}$ for the cerrado. Grace et al. (1995), with measurements of $\mathrm{CO}_{2}$ fluxes at the Jaru Reserve in Rondônia, Brazil $\left(10.08^{\circ} \mathrm{S}\right.$, $61.94^{\circ} \mathrm{W}$ ) in September 1992, estimated an accumulation of $0.09 \mathrm{molC} \mathrm{m}^{-2} \mathrm{day}^{-1}$ for forest during the dry season. So, the forest uptake estimation based on our modeling results is approximately $30 \%$ lower than the estimations based on the Grace et al. (1995) measurements. However, several measurements in the Amazon indicated both high yearly and regional variabilities around the Amazon Basin due to several factors, which include hydric stress, aerosol loads, topography, and differences in soil carbon and forest physiology. Also, previous studies indicated that there are high uncertainties in the magnitude of nocturnal NEE measurements because of the lack of turbulence in and above the forest (Araujo et al., 2002, 2010). In Table 3 we collected from the literature some estimates of NEE (daily total, nighttime and daytime peak) based on $\mathrm{CO}_{2}$ flux measurements in different sites in Amazonia during the dry season in different years. For the same sites, we also present in Table 3 the NEE from the DIR+DIF experiment for September 2010. For example, measurements taken at the Jaru Reserve (the same site used by Grace et al., 1995) and at a grass plot (Fazenda Nossa Senhora (FNS) at $10.762^{\circ} \mathrm{S}, 62.358^{\circ} \mathrm{W}$ ) during the dry season from 1999 to 2002 revealed an uptake of around 0.12 and $0.069 \mathrm{molC} \mathrm{m}^{-2} \mathrm{day}^{-1}$ for the pasture and forest site, respectively, with the diurnal values of NEE reaching -13.2 and $-17.5 \mu \mathrm{molC} \mathrm{m}{ }^{-2} \mathrm{~s}^{-1}$ for the pasture and forest, respectively (von Randow, 2004). More recently, Cirino et al. (2014) reported 10 years of $\mathrm{CO}_{2}$ flux measurements carried out in the central Amazon Cuieiras Biological Reserve flux tower: K34 LBA (Large Scale Biosphere-Atmosphere Experiment in Amazonia; $2.609^{\circ} \mathrm{S}, 6.209^{\circ} \mathrm{W}$ ) from 1999 to 2009 and also in the Jaru Reserve from 1999 to 2002. The measured diurnal cycle of NEE at both sites was, as expected, positive during the nighttime and negative during the daytime. During the dry season, the mean values of NEE measured during the night were approximately $+5.2( \pm 0.8)$ and +6.8 $( \pm 1.0) \mu \mathrm{molC} \mathrm{m}{ }^{-2} \mathrm{~s}^{-1}$ at the Jaru (Von Randow et al., 2004) and Cuieras (Cirino et al., 2014) reserves, respectively, due to differences in the physiology of the forest and possibly the topography in the two sites. There were even more significant differences between the maximum values of carbon uptake between the two sites, which were around -17.5 and $-20 \mu \mathrm{molC} \mathrm{m}^{-2} \mathrm{~s}^{-1}$ under biomass burning and cloudy sky conditions at the Jaru and Cuieras reserves, respectively, and $-18 \mu \mathrm{molC} \mathrm{m}^{-2} \mathrm{~s}^{-1}$ under clean skies in both sites. The differences between the peak values of carbon absorption are likely related to the presence of biomass burning, the variability of cloudiness and rainfall, and soil characteristics, like water content and nutrients $(\mathrm{N}, \mathrm{P})$. Measurements at the
Tapajós National Forest $\left(2.85^{\circ} \mathrm{S}, 55.04^{\circ} \mathrm{W}\right)$ from 2002 to 2005 (during September) led to estimations of NEE varying from +0.017 to $-0.069 \mathrm{molC} \mathrm{m}^{-2} \mathrm{day}^{-1}$ (Hutyra et al., 2007). The mean value of NEE from the model at Tapajós was $-0.032 \mathrm{molC} \mathrm{m}^{-2} \mathrm{day}^{-1}$ for September 2010. The Jaru Reserve is systematically and intensely affected by both local and long-range transported biomass burning aerosols, with monthly means for AOD $(550 \mathrm{~nm})$ during the dry season typically above 0.5 but often above 1.0 ; in contrast, the biomass burning affects in the northern part of the basin, where Cuieras and Tapajós are located, are more episodic (Longo et al., 2009). In addition, the northern part has more variability in terms of rainfall during the dry season compared to the southern part, due mainly to the position of the Inter-Tropical Convergence Zone (ITCZ). So, strong variability in terms of carbon fluxes in the northern part of the Amazon is indeed expected and is really challenging for a low-resolution model to match point measurements. Nevertheless, our modeled monthly mean diurnal cycles of NEE for forest and pasture biomes (Fig. 14c) are remarkably close to the diurnal cycle reported for the Jaru Reserve and FNS, respectively, by von Randow et al. (2004), with the daily total, nighttime, and daytime peak values (Table 3 ) of a similar order of magnitude within the variability observed.

Figure 15 depicts the model results of the DIR+DIF simulation for GPP $\left(\mu \mathrm{molC} \mathrm{m}{ }^{-2} \mathrm{~s}^{-1}\right)$ in response to the available PAR $\left(\mu \mathrm{mol} \mathrm{m}{ }^{-2} \mathrm{~s}^{-1}\right)$ for the four main different biome types in the domain of study and in a range of 0.2 to 0.6 for the fraction of the diffuse irradiance. The analysis is also limited to conditions in which the soil wetness is above 0.9 . The maximum values of GPP for forest and C3 grass are reached with PAR around 1600 and $1300 \mathrm{~mol} \mathrm{~m}^{-2} \mathrm{~s}^{-1}$, respectively, indicating that these are the saturation point for these biomes relative to the amount of energy reaching the surface. For cerrado (shrubs), the saturation point is much lower, around $600 \mathrm{~mol} \mathrm{~m}^{-2} \mathrm{~s}^{-1}$, but the plants maintain their carbon assimilation rate up to PAR around $1600 \mathrm{~mol} \mathrm{~m}^{-2} \mathrm{~s}^{-1}$ and only then decrease with a further increase in PAR. For the $\mathrm{C} 4$ grass, GPP increases almost linearly with PAR, not showing any evidence of saturation with the amount of energy received. In general, the results in Fig. 15 indicate that for a given biome and PAR value, a higher amount of diffuse radiation implies higher GPP. However, the cerrado (shrubs) biome is an exception since it saturates with relatively lower values of PAR.

The mean spatial distribution of the relative impact of aerosol effects on modeled fluxes at 16:00 UTC is shown in Fig. 16, considering the changes both on direct and diffuse radiation and only on direct solar radiation. In the LBAR where the forest biome dominates, there is an increase in GPP (Fig. 16b1) ranging from 0.1 to $5.0 \mu \mathrm{molC}^{-2} \mathrm{~s}^{-1}$ related to the aerosol effect, the lower values being associated with lower AOD values (Fig. 8) and drier soil (Fig. 5). In the remaining regions, the aerosol impact on GPP is still positive but much lower $\left(0.1-0.5 \mu \mathrm{molC}^{-2} \mathrm{~s}^{-1}\right)$. In all domains, the 

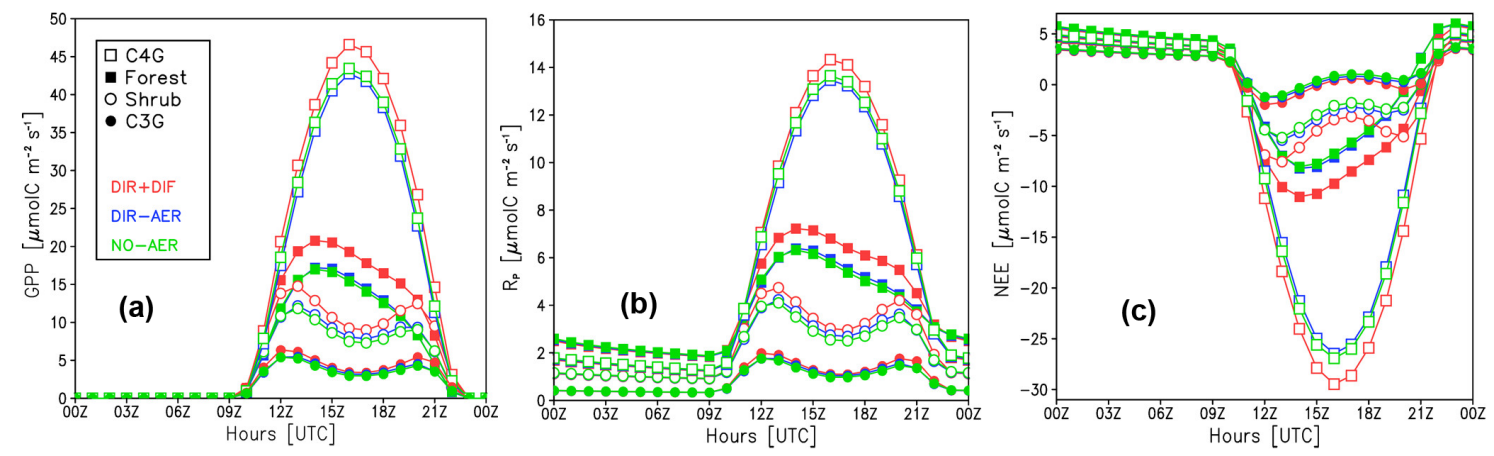

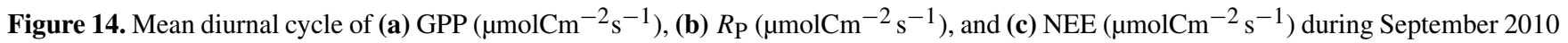
for the different biomes in the LBAR. Different symbols indicate the biomes of forest (filled squares), C3G (hollow circles), C4G (hollow squares), and shrubs (filled circles). Different colors indicate the modeling experiments: green is for NO-AER, blue is for DIR-AER, and red is for DIR+DIF.

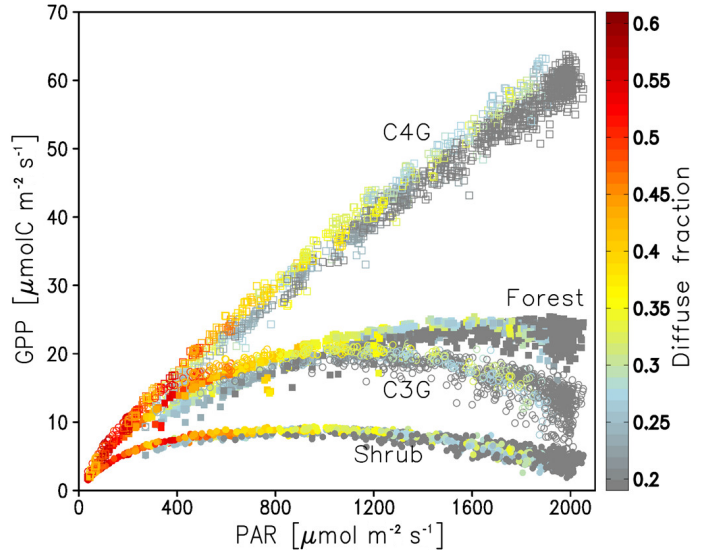

Figure 15. Scatterplots of GPP $\left(\mu \mathrm{molCm}^{-2} \mathrm{~s}^{-1}\right)$ and PAR $\left(\mu\right.$ molm ${ }^{-2} s^{-1}$ ) from the DIR+DIFF experiment for forest (filled squares) and shrub biomes (filled circles) and grass types $\mathrm{C} 4$ (hollow squares) and C3 (hollow circles) during September 2010 (temporal) in the LBAR (spatial). The color scale depicted indicates the fraction of diffuse radiation. The data were filtered for a soil water factor above 0.9 .

majority of the aerosol impact is related to the increase in the diffuse fraction of solar radiation due to the presence of aerosols ( $\left.\% \mathrm{GPP}_{\text {diff }}>95 \%\right)$. As a general rule, our model results indicate that the increase in GPP leads to an increase ranging between 0.2 and $1.6 \mu \mathrm{molC} \mathrm{m}^{-2} \mathrm{~s}^{-1}$ in plant respiration $\left(R_{\mathrm{P}}\right)$ for the forest and does not affect the other biomes significantly. On the other hand, soil respiration $\left(R_{\mathrm{H}}\right.$; row three in Fig. 16) varies from 1 to $8 \mu \mathrm{molC} \mathrm{m}{ }^{-2} \mathrm{~s}^{-1}$, with the higher values in the forest area with higher soil moisture (Fig. 5). The aerosol impact on $R_{\mathrm{H}}$ is somewhat noisy, varying from -1 to $+1 \mu \mathrm{molC} \mathrm{m}^{-2} \mathrm{~s}^{-1}$ over the forest and negative otherwise $\left(\sim-0.1 \mu \mathrm{molC} \mathrm{m}{ }^{-2} \mathrm{~s}^{-1}\right)$. The noise of $R_{\mathrm{H}}$ is associated with the nonlinear effects of aerosol on cloudiness (and thus temperature) and precipitation. The total impact of aerosol in NEE (row four in Fig. 16) ranged from -0.1 to
$-5 \mu \mathrm{molC} \mathrm{m}{ }^{-2} \mathrm{~s}^{-1}$, with the lower values found in the forest region with intense and/or persistent biomass burning mainly related to the diffuse radiation effect, meaning that our modeling suggests that the aerosol biomass burning effect creates a $\mathrm{CO}_{2}$ sink in Amazonia.

\section{Total carbon fluxes in Amazonia weighted for the vegetation types}

Figure 17 depicts the monthly mean diurnal cycle of the $\mathrm{CO}_{2}$ fluxes in the LBAR for September 2010, again related to GPP, $R_{\mathrm{P}}, R_{\mathrm{H}}$, and NEE averaged over the four types of vegetation present in each atmospheric model grid box. The presence of the biomass burning aerosol affects the $\mathrm{CO}_{2}$ flux associated with GPP, and consequently Rp. Responding to the increasing diffuse radiation, both GPP and $R_{\mathrm{P}}$ rise, with a GPP enhancement about 4 times higher than the $R_{\mathrm{P}}$. In contrast, RS has an opposite response as the presence of aerosol implies a cooler soil (Fig. 10) and consequently lower microbial activity. The net effect is a higher $\mathrm{CO}_{2}$ daytime uptake with negligible nighttime variation. Moreover, the biomass burning aerosol strongly impacts the NEE (Fig. 17b). Around noon, the NEE decreases from -7 to $-10 \mu \mathrm{molC}^{-2} \mathrm{~s}^{-1}$ in the presence of biomass burning, mainly due to the diffuse radiation effect. Nevertheless, it is interesting to note that the impact of the aerosol influence on the relative contribution of the diffuse to the total (diffuse + direct) on the NEE (Eq. 4) has different behavior depending on plant functional type and decays exponentially as the AOD increases for all biomes, except for the C4 grass type. The contribution of the diffuse radiation effect to NEE ( $\triangle \mathrm{NEE}_{\text {diff }} / \triangle \mathrm{NEE}_{\text {tot }}$ ) versus AOD for each biome is depicted in Fig. 18 along with its fitting functions. Over forest, the percentage of the diffuse radiation effect on $\mathrm{CO}_{2}$ uptake decreases exponentially $\left(\left[\Delta \mathrm{NEE}_{\text {diff }} / \Delta \mathrm{NEE}_{\text {tot }}\right]_{\text {forest }} \approx\right.$ $\left.e^{-0.9 \mathrm{AOD}} ; R^{2}=0.7\right)$ from 100 to $50 \%$ with the increase in aerosol loading, reaching a balance of $50-50 \%$ between the diffuse and direct effect for AOD above 0.5. 

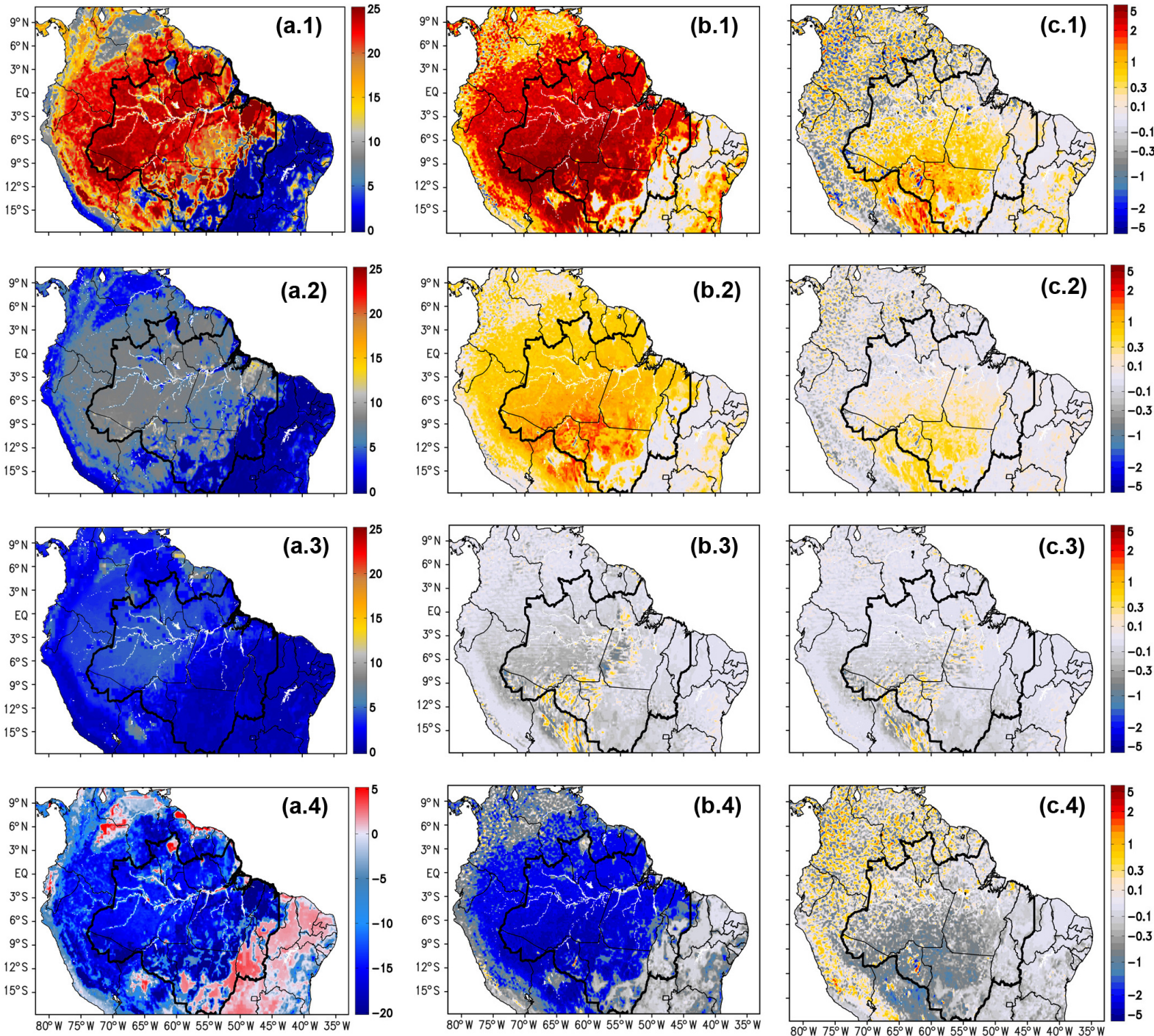

Figure 16. Mean net $\mathrm{CO}_{2}$ fluxes $\left(\mu \mathrm{molCm}{ }^{-2} \mathrm{~s}^{-1}\right.$ ) weighted per biome type for September 2010 at 16:00 UTC (column a). The differences in the mean $\mathrm{CO}_{2}$ fluxes as simulated in DIR+DIF and NO-AER (column b) and in DIR-AER and NO-AER (column c) during the same time period. The first to the fourth rows indicate the results for GPP, $R_{\mathrm{P}}, R_{\mathrm{H}}$, and NEE processes, respectively. The darker black contour line on the maps delimits the LBAR.

Table 4. Total $\mathrm{CO}_{2}$ assimilation ratio for the DIR+DIF simulation, $\Delta$ Flux tot, and $\Delta$ Flux $\mathrm{dir}_{\text {ir }}$ in the LBAR during September 2010 for the different atmosphere-biosphere exchange processes.

\begin{tabular}{lrrr|rr}
\hline Process & $\begin{array}{r}\mathrm{CO}_{2} \text { Flux } \\
{\left[\mathrm{TgCmonth}^{-1}\right]}\end{array}$ & $\begin{array}{c}\Delta \text { Flux }_{\text {tot }} \\
{\left[\mathrm{TgCmonth}^{-1}\right]}\end{array}$ & {$[\%]$} & $\begin{array}{r}\Delta \text { Flux }_{\text {dir }} \\
{\left[\text { TgCmonth }^{-1}\right]}\end{array}$ & {$[\%]$} \\
\hline GPP & 1113 & 240 & 27 & 1 & 0 \\
$R_{p}$ & 560 & 50 & 10 & 0 & 0 \\
$R_{\mathrm{H}}$ & 449 & -14 & -3 & -7 & -2 \\
NEE & -104 & -205 & -203 & -8 & 8 \\
\hline
\end{tabular}

For C3 grass and cerrado, as expected, the contribution of the diffuse radiation effects tends to zero with the increase in $\mathrm{AOD}\left(\left[\Delta \mathrm{NEE}_{\mathrm{diff}} / \Delta \mathrm{NEE}_{\text {tot }}\right]_{\mathrm{cerrado}, \mathrm{C} 3} \approx 0.7 e^{-4 \mathrm{AOD}} ; R^{2}=\right.$
0.7). For the $\mathrm{C} 4$ grass type, the contribution of the diffuse radiation to NEE exponentially increases with AOD $\left(\left[\Delta \mathrm{NEE}_{\mathrm{diff}} / \Delta \mathrm{NEE}_{\mathrm{tot}}\right]_{\mathrm{C} 4} \approx e^{\mathrm{AOD}} ; R^{2}=0.9\right)$, and the $\mathrm{C} 4$ 

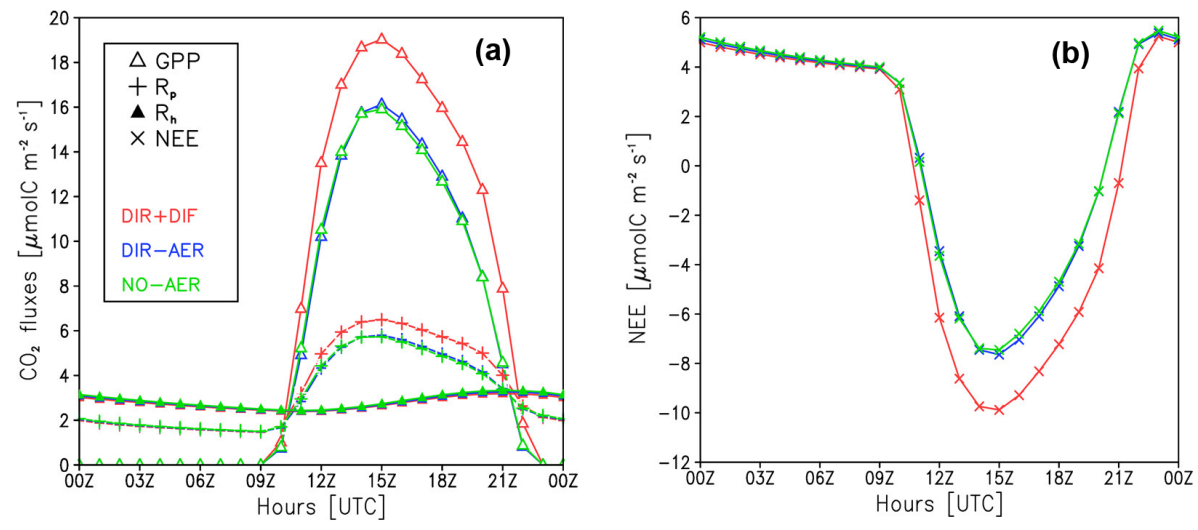

Figure 17. (a) Mean diurnal cycle of $\mathrm{CO}_{2}$ fluxes $\left(\mu \mathrm{molCm}{ }^{-2} \mathrm{~s}^{-1}\right)$ during September 2010 in the LBAR, with different symbols indicating the processes of GPP (hollow triangles), $R_{\mathrm{P}}$ (plus symbols), and $R_{\mathrm{H}}$ (filled triangles). (b) Mean diurnal cycle of $\mathrm{CO}_{2} \mathrm{fluxes}\left(\mu \mathrm{molCm}{ }^{-2} \mathrm{~s}^{-1}\right.$ ) associated with NEE during the same period and in the same area. In both plots, different colors indicate the modeling experiments: green is for NO-AER, blue is for DIR-AER, and red is for DIR+DIF.

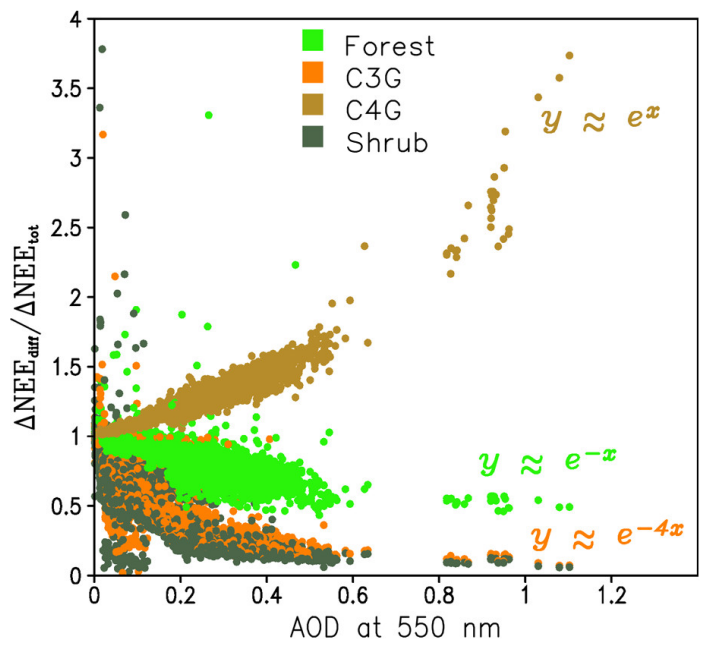

Figure 18. The contribution of the diffuse radiation effect to NEE $\left(\triangle \mathrm{NEE}_{\text {diff }} / \Delta \mathrm{NEE}_{\mathrm{tot}}\right)$ as a function of AOD in the LBAR, but separated with different colors for different types of vegetation. The model data were filtered for cloudiness and precipitation. Additionally, only model points with the same soil water factor for all three experiments and a soil moisture difference below $0.001 \mathrm{~m}^{3} \mathrm{~m}^{-3}$ were included. The fitting functions of the $\Delta \mathrm{NEE}_{\text {diff }} / \Delta \mathrm{NEE}_{\text {tot }}$ versus AOD for each biome are also shown in the figure.

photosynthetic pathway does not rapidly saturate with the amount of light received. Considering the AOD underestimation of about $20 \%$ and the exponential behavior of the relative contribution of the diffuse fraction to NEE, it is reasonable to say that the contribution of the diffuse radiation effect on $\mathrm{CO}_{2}$ uptake can reach $40 \%$ over the forest and $10 \%$ over cerrado and the $\mathrm{C} 3$ grass type for high aerosol loads.

The model results for the $\mathrm{CO}_{2}$ fluxes integrated for the month of September (2010), which is the peak of the burning season in the LBAR, are summarized in Table 4. Total modeled GPP in the LBAR is $1113 \mathrm{Tg} \mathrm{C}$ with the aerosol being responsible for an increase of $240 \mathrm{Tg} \mathrm{C}$, with less than $1 \%$ due to the aerosol radiation direct effect. Plant respiration is affected by approximately $50 \mathrm{Tg} \mathrm{C}$, related only to the increase in the diffuse fraction of radiation. The impact of the aerosol on the soil respiration is only $3 \%$ but in the opposite direction, i.e., a reduction. Integrating throughout the full month for September 2010, the NEE changed from +101 to $-104 \mathrm{Tg} \mathrm{C}$ when the aerosol effect is considered. The total aerosol effect on radiation was responsible for about $96 \%$ of the NEE change, while the temperature reduction due to the direct aerosol effect on radiation accounts for only $5 \%$. That is, the aerosol effect, especially the change in the diffuse fraction of radiation, is strong enough to invert the signal of NEE, changing the ecosystem from being a source to a sink of $\mathrm{CO}_{2}$. Table 3 shows that the NEE observed during the dry season at the Amazon forest and pasture biomes exhibits substantial site-to-site and interannual variability. Nevertheless, for each site, the 2010 model results are within the observed variability.

\section{Conclusions and final remarks}

We conducted a modeling study during the peak of the burning season in Amazonia to assess the ability of a current state-of-the-art integrated in-line numerical atmospheric modeling system to simulate the $\mathrm{CO}_{2}$ fluxes in Amazonia. A set of three different modeling experiments was conducted: first totally disregarding aerosol biomass burning effect, then considering only the direct aerosol effect, and finally also adding the aerosol effect on the diffuse fraction of radiation. The model results allowed us to assess and quantify the impacts of biomass burning aerosols on $\mathrm{CO}_{2}$ fluxes in the Amazon Basin during the dry season. Moreover, the relative role of the main soil, vegetation, and atmosphere interac- 
tion processes controlling the carbon cycle in Amazonia was weighed, and the aerosol effect on each of them was measured separately.

Consistent with previous studies (Freitas et al., 2005, 2009, 2017; Longo et al., 2010, 2013; Rosário et al., 2013; Moreira et al., 2013), BRAMS performed well while modeling the meteorology and aerosol biomass burning emission, transport, and removal processes in Amazonia, which has resulted in accurate simulation of the major features of AOD variability associated with the regional biomass burning plume over South America. The model results for surface temperature, rainfall, and AOD were once again in agreement with observations for the 2010 dry season case study, representing the main characteristics of the spatial distribution and the diurnal cycle of temperature and precipitation. BRAMS was also evaluated on its performance to simulate $\mathrm{CO}$ and $\mathrm{CO}_{2}$ mixing ratios using measurements acquired from air samples collected using light aircraft over the Amazon during the 2010 and 2011 burning seasons. Typically, the model tends to slightly underestimate the $\mathrm{CO}$ mixing ratio, particularly in the lower levels, in regions affected by fresh biomass burning and haze biomass burning layers. Previous studies had already indicated an underestimation of the biomass burning emissions database used in this work (3BEM; Longo et al., 2010) of about 20\% (Andreae et al., 2012), mainly related to fire omission and misrepresentation of the vegetation and carbon maps used (Pereira et al., 2016). For $\mathrm{CO}_{2}$ mixing ratios, the comparison between model and observation is highly scattered, again especially in the lower levels, though in this case more likely related to convective activity pumping $\mathrm{CO}_{2}$ to the upper layers of the atmosphere and inaccurate modeling of surface carbon net fluxes (NEE). In both cases, model inaccuracies are at least partially related to the lower model resolution $(20 \mathrm{~km})$, suggesting that further sensitivity studies on model resolution would be helpful. Nevertheless, although the $20 \mathrm{~km}$ model resolution was not capable of capturing $\mathrm{CO}_{2}$ point measurements in Amazonia, the order of magnitude of the $\mathrm{CO}_{2}$ mixing ratio has been in general well represented. Moreover, the diurnal cycle of $\mathrm{CO}_{2}$ measured above the canopy of the Tapajós forest was represented in the model with differences of only about -0.9 and $+1.4 \%$ between model results and observations during the time of minimum and maximum values, respectively.

Our modeling results indicate that during the dry season in Amazonia, regions with lower precipitation do not always have high values of NEE because the lower soil respiration of a dryer soil can compensate for the deficit of water available for plants (e.g., Saleska et al., 2003). Being an equatorial region, Amazonia receives abundant PAR. Therefore, areas with plenty of water availability in the soil have higher GPP compared to dry soil areas. However, after noon local time, when the radiation excess typically occurs, there is a drop in carbon assimilation for all biomes, except for the $\mathrm{C} 4$ grass type that has maximum assimilation coinciding with the peak of PAR.
The presence of an intense biomass burning aerosol layer during the dry season over Amazonia reduces the solar energy reaching the surface, consequently reducing nearsurface temperature. The model results show this cooling effect contributing to increasing the GPP in regions covered by forest, grass C3, and cerrado. However, in addition to reducing the surface energy, the aerosol layer also increases the diffuse fraction of radiation. This is the major effect that contributes to increasing GPP and, in this case, including the C4 grass type biome. These two effects together increase GPP by about 32, 30, 9, and $20 \%$ for forest, C3 grasses, C4 grasses, and cerrado, respectively.

In the LBAR, the GPP increased about $27 \%$, reaching $1113 \mathrm{TgC}$ during September 2010, when the aerosol effects were included. Plant respiration also increased from 510 to $560 \mathrm{TgC}$, with the aerosol biomass burning effect as a response to the increase in GPP. The more $\mathrm{CO}_{2}$ the plant assimilates to produce sugar, the more it needs to increase its respiration for energy supply. On the other side, soil respiration dropped from 463 to $449 \mathrm{Tg} \mathrm{C}$. Consequently, the NEE in the LBAR during September 2010 dropped from +101 to $-104 \mathrm{TgC}$ when the aerosol effects were considered, mainly due to the diffuse radiation effect. That is, the LBAR during the dry season, in the presence of high biomass burning aerosol loads, changes from a source to a sink of $\mathrm{CO}_{2}$ to the atmosphere. These results are also consistent with the observations of Yamasoe et al. (2006), who found no correlation between NEE and aerosol load for low AOD values $(<0.7)$; however, for AOD > 0.7 NEE values became negative, and for AOD $>1.5-2$ NEE started to increase again. Our model results also indicate that the impact of the aerosol on the NEE change is mainly related to the aerosol increasing the diffuse fraction of radiation. For AOD higher than 0.5, the forest reaches a balance of 50-50\% between the diffuse and direct aerosol effects. For the $\mathrm{C} 3$ grass type and cerrado, as expected, the contribution of the diffuse radiation effect is much lower than for the forest biome and tends to near zero with the increase in AOD. Direct measurements at the Tapajós site (Doughty et al., 2010) led to an estimation of the relative aerosol contribution in $\mathrm{CO}_{2}$ uptake, for high values of $\mathrm{AOD}$, of $80 \%$ as a result of increased shaded light in the sub-canopy related to the effect of aerosol increasing the diffuse fraction of radiation. Only $20 \%$ of the aerosol impact on $\mathrm{CO}_{2}$ uptake was attributed to the decrease in canopy temperature. These same authors, however, do recognize that is "difficult to know whether this proportion is applicable to forest biomes worldwide or limited to tropical forest". So, based on our model results, we go even further and say that it is difficult to even to affirm that there is a unique rule applicable to the entire Amazon forest due to its high diversity of plant and soil characteristics and microclimates.

Considering that the fire activity in Amazonia typically lasts for about 3 months, we can estimate as a first approximation that the net impact of biomass burning aerosols on

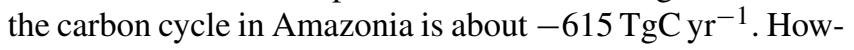


ever, we must say that the fire activity in 2010 was very intense (see Fig. S7), and therefore this estimation is not likely to be representative of an average year. According to Espírito-Santo et al. (2014), the impact of the natural disturbance in the carbon cycle in Amazonia is generally around $1300 \mathrm{TgC} \mathrm{yr}^{-1}$. Thus, the aerosol (negative) impact can be of a similar order of magnitude as the (positive) impact of the natural disturbances in the carbon cycle in Amazonia.

Our model results emphasize the importance of considering the effects of aerosol in numerical models of climate forecasting, especially when investigating the intensification of the greenhouse effect due to the atmospheric $\mathrm{CO}_{2}$ concentration. In general, the numerical results obtained were in good agreement with observational data, including meteorological, aerosol, and trace gas variables, which gives us confidence in the estimation of the carbon fluxes. However, we do recognize that including the effect of cloudiness on the diffuse fraction of radiation is an essential model capability that will allow us to explore the relative impact of biomass burning aerosol and clouds as well as the seasonality and annual variability of the carbon cycle in Amazon. This is a work in progress and we will soon report the inclusion of the cloud effect on the diffuse fraction of solar radiation in the model, which certainly has a major effect on the $\mathrm{CO}_{2}$ budget in Amazonia during the wet season.

In addition, further model development based on the current level of knowledge could still improve the representation of biomass burning aerosol effects in the carbon cycle. As such, model studies that include a reduction in photosynthesis due to the oxidation of plant leaves by high levels of ozone secondarily produced in biomass burning plumes and the indirect aerosol effect on $\mathrm{CO}_{2}$ is also a work in progress.

Data availability. The BRAMS model and its input data can be downloaded from http://brams.cptec.inpe.br/downloads/. $\mathrm{CO}_{2}$ and $\mathrm{CO}$ airbone data, $\mathrm{CO}_{2}$ tower data, radiation data, and other relevant data are available upon request to the authors: Luciana V. Gatti (lvgatti@gmail.com), Kenia T. Wiedemann (keniatw@seas.harvard.edu), Marcia A. Yamasoe (marcia.yamasoe@iag.usp.br), and Demerval S. Moreira (demerval@fc.unesp.br).

\section{The Supplement related to this article is available online at https://doi.org/10.5194/acp-17-14785-2017- supplement.}

Author contributions. DSM and KML prepared the paper. LMM, NER, MAY, JBM, SRF, and EG reviewed the paper. DSM, SRF, KML, and NER contributed to BRAMS code development. LMM contributed to JULES code development and the JULES-BRAMS model coupling. DSM designed and executed the numerical experiments. DSM, KML, SRF, and RSMV worked on model validation, evaluation, and results analysis. MAY and NER provided aerosol and radiation observational data and analysis. Finally, JBM, LVG, KTW, LKGD, and CCSC provided carbon flux observational data.

Competing interests. The authors declare that they have no conflict of interest.

Special issue statement. This article is part of the special issue "Coupled chemistry-meteorology modelling: status and relevance for numerical weather prediction, air quality and climate communities (SI of EuMetChem COST ES1004; ACP/GMD inter-journal SI)". It is not associated with a conference.

Acknowledgements. We thank Clara Longo de Freitas for reviewing the final paper.

Edited by: Alexander Baklanov

Reviewed by: two anonymous referees

\section{References}

Andreae, M. O., Artaxo, P., Beck, V., Bela, M., Freitas, S., Gerbig, C., Longo, K., Munger, J. W., Wiedemann, K. T., and Wofsy, S. C.: Carbon monoxide and related trace gases and aerosols over the Amazon Basin during the wet and dry seasons, Atmos. Chem. Phys., 12, 6041-6065, https://doi.org/10.5194/acp12-6041-2012, 2012.

Andreae, M. O., Rosenfeld, D., Artaxo, P., Costa, A. A., Frank, G. P., Longo, K. M., and Silva-Dias, M. A. F.: Smoking rain clouds over the Amazon, Science, 303, 1337-1342, https://doi.org/10.1126/science.1092779, 2004.

Andreae, M. O., Artaxo, P., Brandão, C., Carswell, F. E., Ciccioli, P., da Costa, A. L., Culf, A. D., Esteves, J. L., Gash, J. H.C., Grace, J., Kabat, P., Lelieveld, J., Malhi, Y., Manzi, A. O., Meixner, F. X., Nobre, A. D., Nobre, C., Ruivo, M. d. L. P., Silva-Dias, M. A., Stefani, P., Valentini, R., von Jouanne, J., and Waterloo, M. J.: Biogeochemical cycling of carbon, water, energy, trace gases, and aerosols in Amazonia: The LBA-EUSTACH experiments, J. Geophys. Res.-Atmos., 107, LBA 33-1-LBA 33-25, https://doi.org/10.1029/2001JD000524, 2002.

Andreae, M. and Merlet, P.: Emission of trace gases and aerosols from biomass burning, Global Biogeochem. Cy., 15, 955-966, 2001.

Araujo, A. C., Dolman, A. J., Waterloo, M. J., Gash, J. H. C., Kruijt, B., Zanchi, F. B., de Lange, J. M. E., Stoevelaar, R., Manzi, A. O., Nobre, A. D., Lootens, R. N., and Backer, J.: The spatial variability of $\mathrm{CO}_{2}$ storage and the interpretation of eddy covariance fluxes in central Amazonia, Agr. Forest Meteorol., 150, 226-237, 2010.

Araujo, A. C., Nobre, A. D., Kruijt, B., Elbers, J. A., Dallarosa, R., Stefani, P., von Randow, C., Manzi, A. O., Culf, A. D., Gash, J. H. C., Valentini, R., and Kabat, P.: Comparative measurements of carbon dioxide fluxes from two nearby towers in a central Amazonian rainforest: the Manaus LBA site, J. Geophys. Res.Atmos., 107, 8090, https://doi.org/10.1029/2001jd000676, 2002. 
Baldocchi, D.: Measuring and modelling carbon dioxide and water vapour exchange over a temperate broad-leaved forest during the 1995 summer drought, Plant Cell Environ., 20, 1108-1122, https://doi.org/10.1046/j.1365-3040.1997.d01-147.x, 1997.

Best, M. J., Pryor, M., Clark, D. B., Rooney, G. G., Essery, R .L. H., Ménard, C. B., Edwards, J. M., Hendry, M. A., Porson, A., Gedney, N., Mercado, L. M., Sitch, S., Blyth, E., Boucher, O., Cox, P. M., Grimmond, C. S. B., and Harding, R. J.: The Joint UK Land Environment Simulator (JULES), model description Part 1: Energy and water fluxes, Geosci. Model Dev., 4, 677-699, https://doi.org/10.5194/gmd-4-677-2011, 2011.

Bruno, R. D., da Rocha, H. R., de Freitas, H. C., Goulden, M. L., and Miller, S. D.: Soil moisture dynamics in an eastern Amazonian tropical forest, Hydrol. Process., 20, 2477-2489, https://doi.org/10.1002/hyp.6211, 2006.

Cirino, G. G., Souza, R. A. F., Adams, D. K., and Artaxo, P.: The effect of atmospheric aerosol particles and clouds on net ecosystem exchange in the Amazon, Atmos. Chem. Phys., 14, 6523-6543, https://doi.org/10.5194/acp-14-6523-2014, 2014.

Clark, D. B., Mercado, L. M., Sitch, S., Jones, C. D., Gedney, N., Best, M. J., Pryor, M., Rooney, G. G., Essery, R. L. H., Blyth, E., Boucher, O., Harding, R. J., Huntingford, C., and Cox, P. M.: The Joint UK Land Environment Simulator (JULES), model description - Part 2: Carbon fluxes and vegetation dynamics, Geosci. Model Dev., 4, 701-722, https://doi.org/10.5194/gmd-4701-2011, 2011.

Cochrane, M. A. and Laurance, W. F.: Synergisms among fire, land use, and climate change in the Amazon, Ambio, 37, 522-527, 2008.

Collatz, G. J., Ball, J. T., Grivet, C., and Berry, J. A.: Physiological and environmental regulation of stomatal conductance, photosynthesis and transpiration: a model that includes a laminar boundary layer, Agr. Forest Meteorol., 54, 107-136, https://doi.org/10.1016/0168-1923(91)90002-8, 1991.

Dai, Y. J., Dickinson, R. E., and Wang, Y. P.: A two-big-leaf model for canopy temperature, photosynthesis, and stomatal conductance, J. Climate, 17, 2281-2299, 2004.

Doughty, C. E., Flanner, M. G., and Goulden, M. L.: Effect of smoke on subcanopy shaded light, canopy temperature, and carbon dioxide uptake in an Amazon rainforest, Global Biogeochem. Cy., 24, 1944-9224, https://doi.org/10.1029/2009GB003670, 2010.

Duncan, B. N. and Logan, J. A.: Model analysis of the factors regulating the trends and variability of carbon monoxide between 1988 and 1997, Atmos. Chem. Phys., 8, 7389-7403, https://doi.org/10.5194/acp-8-7389-2008, 2008.

Espírito-Santo, F. D. B., Gloor, M., Keller, M., Malhi, Y., Saatchi, S., Nelson, B., Oliveira Junior, R. C., Pereira, C., Lloyd, J., Frolking, S., Palace, M., Shimabukuro, Y. E., Duarte, V., Mendoza, A. M., López-González, G. L., Baker, T. R., Feldpausch, T.R., Brienen, R. J. W., Asner, G. P., Boyd, D. S., and Phillips, O. L.: Size and frequency of natural forest disturbances and the Amazon forest carbon balance, Nat. Commun., 5, 3434, https://doi.org/10.1038/ncomms4434, 2014.

Feeley, K. J., Joseph Wright, S., Nur Supardi, M. N., Kassim, A. R., and Davies, S. J.: Decelerating growth in tropical forest trees, Ecol. Lett., 10, 461-469, https://doi.org/10.1111/j.14610248.2007.01033.x, 2007.
Freitas, S. R., Longo, K. M., Silva Dias, M. A.F., Silva Dias, P. L., Chatfield, R., Prins, E., Artaxo, P., Grell, G. A., and Recuero, F. S.: Monitoring the transport of biomass burning emissions in South America, Environ. Fluid Mech., 5, 135-167, https://doi.org/10.1007/s10652-005-0243-7, 2005.

Freitas, S. R., Panetta, J., Longo, K. M., Rodrigues, L. F., Moreira, D. S., Rosário, N. E., Silva Dias, P. L., Silva Dias, M. A. F., Souza, E. P., Freitas, E. D., Longo, M., Frassoni, A., Fazenda, A. L., Santos e Silva, C. M., Pavani, C. A. B., Eiras, D., França, D. A., Massaru, D., Silva, F. B., Santos, F. C., Pereira, G., Camponogara, G., Ferrada, G. A., Campos Velho, H. F., Menezes, I., Freire, J. L., Alonso, M. F., Gácita, M. S., Zarzur, M., Fonseca, R. M., Lima, R. S., Siqueira, R. A., Braz, R., Tomita, S., Oliveira, V., and Martins, L. D.: The Brazilian developments on the Regional Atmospheric Modeling System (BRAMS 5.2): an integrated environmental model tuned for tropical areas, Geosci. Model Dev., 10, 189-222, https://doi.org/10.5194/gmd-10-189-2017, 2017.

Freitas, S. R., Longo, K. M., Trentmann, J., and Latham, D.: Technical Note: Sensitivity of 1-D smoke plume rise models to the inclusion of environmental wind drag, Atmos. Chem. Phys., 10, 585-594, https://doi.org/10.5194/acp-10-585-2010, 2010.

Freitas, S. R., Longo, K. M., Silva Dias, M. A. F., Chatfield, R., Silva Dias, P., Artaxo, P., Andreae, M. O., Grell, G., Rodrigues, L. F., Fazenda, A., and Panetta, J.: The Coupled Aerosol and Tracer Transport model to the Brazilian developments on the Regional Atmospheric Modeling System (CATT-BRAMS) Part 1: Model description and evaluation, Atmos. Chem. Phys., 9, 2843-2861, https://doi.org/10.5194/acp-9-2843-2009, 2009.

Freitas, S. R., Longo, K. M., Chatfield, R., Latham, D., Silva Dias, M. A. F., Andreae, M. O., Prins, E., Santos, J. C., Gielow, R., and Carvalho Jr., J. A.: Including the sub-grid scale plume rise of vegetation fires in low resolution atmospheric transport models, Atmos. Chem. Phys., 7, 3385-3398, https://doi.org/10.5194/acp7-3385-2007, 2007.

Gatti, L. V., Miller, J. B., D’Amelio, M. T. S., Martinewski, A., Basso, L. S., Gloor, M. E., Wofsy, S., and Tans, P.: Vertical profiles of $\mathrm{CO}_{2}$ above eastern Amazonia suggest a net carbon flux to the atmosphere and balanced biosphere between 2000 and 2009, Tellus B, 62, 581-594, https://doi.org/10.1111/j.16000889.2010.00484.x, 2010.

Gatti, L. V., Gloor, M., Miller, J. B., Doughty, C. E., Malhi, Y., Domingues, L. G., Basso, L. S., Martinewski, A., Correia, C. S. C., Borges, V. F., Freitas, S., Braz, R., Anderson, L. O., Rocha, H., Grace, J., Phillips, O. L., and Lloyd, J.: Drought sensitivity of Amazonian carbon balance revealed by atmospheric measurements, Nature, 506, 76-80, https://doi.org/10.1038/nature12957, 2014.

Gevaerd, R. and Freitas, S. R.: Estimativa operacional da umidade do solo para inicializaçãao de modelos de previssão numérica da atmosfera, Parte I: Descrição da metodologia e validação, Revista Brasileira de Meteorologia, 21, 1-15, 2006 (in Portuguese).

Giglio, L., Descloitres, J., Justice, C. O., and Kaufman, Y. J.: An enhanced contextual fire detection algorithm for MODIS, Remote Sens. Environ., 87, 273-282, 2003.

Grace, J., Lloyd, J., Mcintyre, J., Miranda, A. C., Meir, P., Miranda, H. S., Nobre, C., Moncrieff, J., Massheder, J., Malhi, Y., Wright, I., and Gash, J.: Carbon dioxide uptake by an undisturbed tropical rain forest in southwest Amazonia, 1992 to 1993, Science, 270, 778, https://doi.org/10.1126/science.270.5237.778, 1995. 
Grell, G. A. and Freitas, S. R.: A scale and aerosol aware stochastic convective parameterization for weather and air quality modeling, Atmos. Chem. Phys., 14, 5233-5250, https://doi.org/10.5194/acp-14-5233-2014, 2014.

Harrison, L. and Michalsky, J.: Objective algorithms for the retrieval of optical depths from ground-based measurements, Appl. Opt., 33, 5126-5132, 1994.

Harrison, L., Michalsky, J., and Berndt, J.: Automated multifilter rotating shadow-band radiometer: an instrument for optical depth and radiation measurements, Appl. Opt., 33, 5118-5125, 1994.

Hoelzemann, J. J., Longo, K. M., Fonseca, R. M., do Rosário, N. M., E., Elbern, H., Freitas, S. R., and Pires, C.: Regional representativity of AERONET observation sites during the biomass burning season in South America determined by correlation studies with MODIS Aerosol Optical Depth, J. Geophys. Res., 114, D13301, https://doi.org/10.1029/2008jd010369, 2009.

Holloway, T., Levy, H., and Kasibhatla, P.: Global distribution of carbon monoxide, J. Geophys. Res., 105, 12123-12147, 2000.

Hutyra, L. R., Munger, J. W., Saleska, S. R., Gottlieb, E., Daube, B. C., Dunn, A. L., Amaral, D. F., de Camargo, P. B., and Wofsy, S. C.: Seasonal controls on the exchange of carbon and water in an Amazonian rain forest, J. Geophys. Res.-Biogeo., 112, https://doi.org/10.1029/2006JG000365, 2007.

James, S. E., Pärtel, M., Wilson, S. D., and Peltzer, D. A.: Temporal heterogeneity of soil moisture in grassland and forest, J. Ecol., 91, 234-239, 2003.

Jenkinson, D. S., Andrew, S. P. S., Lynch, J. M., Goss, M. J., and Tinker, P. B.: The Turnover of Organic Carbon and Nitrogen in Soil [and Discussion], Philos. Trans. Biol. Sci., 329, 361-368, 1990.

Kanniah, K. D., Beringer, J., North, P., and Hutley, L.: Control of atmospheric particles on diffuse radiation and terrestrial plant productivity: A review, Prog. Phys. Geog., 36, 209-237, 2012.

Kaufman, Y. J.: Remote sensing of direct and indirect aerosol forcing, in: Aerosol Forcing of Climate, edited by: Charlson, R. J. and Heintzenberg, J., John Wiley \& Sons, New York, 297-332, 1995.

Kawanishi, T., Kuroiwa, H., Kojima, M., Oikawa, K., Kozu, T., Kumagai, H., Okamoto, K., Okumura, M., Nakatsuka, H., and Nishikawa, K.: TRMM precipitation radar, Adv. Space Res., 25, 969-972, https://doi.org/10.1016/S0273-1177(99)00932-1, 2000.

Knohl, A. and Baldocchi, D. D.: Effects of diffuse radiation on canopy gas exchange processes in a forest ecosystem, J. Geophys. Res.-Biogeo., 113, 2156-2202, https://doi.org/10.1029/2007JG000663, 2008.

Krol, M. C., Hooghiemstra, P. B., van Leeuwen, T. T., van der Werf, G. R., Novelli, P. C., Deeter, M. N., Aben, I., and Röckmann, T.: Correction to "Interannual variability of carbon monoxide emission estimates over South America from 2006 to 2010": CORRECTIONS, J. Geophys. Res.-Atmos., 118, 5061-5064, https://doi.org/10.1002/jgrd.50389, 2013.

Krol, M., Houweling, S., Bregman, B., van den Broek, M., Segers, A., van Velthoven, P., Peters, W., Dentener, F., and Bergamaschi, P.: The two-way nested global chemistry-transport zoom model TM5: algorithm and applications, Atmos. Chem. Phys., 5, 417-432, https://doi.org/10.5194/acp-5-417-2005, 2005.
Köchy, M. and Wilson, S. D.: Competitive effects of shrubs and grasses in prairie, Oikos, 91, 385-395, https://doi.org/10.1034/j.1600-0706.2000.910219.x, 2000.

Koren, I., Kaufman, Y. J., Remer, L. A., and Martins, J. V.: Measurement of the effect of Amazon smoke on inhibition of cloud formation, Science, 303, 1342-1345, https://doi.org/10.1126/science.1089424, 2004.

Kummerow, C., Olson, W. S., and Giglio, L.: A simplified scheme for obtaining precipitation and vertical hydrometer profiles from passive microwave sensors, IEEE T. Geosci. Remote, 34, 1213 1232, 1996.

Longo, K. M., Freitas, S. R., Pirre, M., Marécal, V., Rodrigues, L. F., Panetta, J., Alonso, M. F., Rosário, N. E., Moreira, D. S., Gácita, M. S., Arteta, J., Fonseca, R., Stockler, R., Katsurayama, D. M., Fazenda, A., and Bela, M.: The Chemistry CATT-BRAMS model (CCATT-BRAMS 4.5): a regional atmospheric model system for integrated air quality and weather forecasting and research, Geosci. Model Dev., 6, 1389-1405, https://doi.org/10.5194/gmd6-1389-2013, 2013.

Longo, K. M., Freitas, S. R., Andreae, M. O., Setzer, A., Prins, E., and Artaxo, P.: The Coupled Aerosol and Tracer Transport model to the Brazilian developments on the Regional Atmospheric Modeling System (CATT-BRAMS) - Part 2: Model sensitivity to the biomass burning inventories, Atmos. Chem. Phys., 10, 57855795, https://doi.org/10.5194/acp-10-5785-2010, 2010.

Longo, K., Freitas, S. R., Andreae, M.O., Yokelson, R., and Artaxo, P.: Biomass burning in Amazonia: emissions, long range transport of smoke and Its regional and remote Impacts, in: Amazonia and Global Change, by the American Geophysical Union Press, edited by: Gash, J. and Keller, M., Mercedes Bustamante, Pedro Silva Dias, 2009.

Mann, G. W., Carslaw, K. S., Spracklen, D. V., Ridley, D. A., Manktelow, P. T., Chipperfield, M. P., Pickering, S. J., and Johnson, C. E.: Description and evaluation of GLOMAP-mode: a modal global aerosol microphysics model for the UKCA composition-climate model, Geosci. Model Dev., 3, 519-551, https://doi.org/10.5194/gmd-3-519-2010, 2010.

Mellor, G. L. and Yamada, T.: Development of a turbulence closure model for geophysical fluid problems, Rev. Geophys., 20, 851875, https://doi.org/10.1029/RG020i004p00851, 1982.

Mercado, L. M., Bellouin, N., Sitch, S., Boucher, O., Huntingford, C., Wild, M., and Cox, P. M.: Impact of changes in diffuse radiation on the global land carbon sink, Nature, 458, 1014 1017, https://doi.org/10.1038/nature07949, 2009.

Min, Q.: Impacts of aerosols and clouds on forest-atmosphere carbon exchange, J. Geophys. Res.-Atmos., 110, 2156-2202, https://doi.org/10.1029/2004JD004858, 2005.

Misson, L., Lunden, M., McKay, M., and Goldstein, A. H.: Atmospheric aerosol light scattering and surface wetness influence the diurnal pattern of net ecosystem exchange in a semi-arid ponderosa pine plantation, Agr. Forest Meteorol., 129, 69-83, https://doi.org/10.1016/j.agrformet.2004.11.008, 2005.

Moreira, D. S., Freitas, S. R., Bonatti, J. P., Mercado, L. M., Rosário, N. M. É., Longo, K. M., Miller, J. B., Gloor, M., and Gatti, L. V.: Coupling between the JULES land-surface scheme and the CCATT-BRAMS atmospheric chemistry model (JULESCCATT-BRAMS1.0): applications to numerical weather forecasting and the $\mathrm{CO}_{2}$ budget in South America, Geosci. Model 
Dev., 6, 1243-1259, https://doi.org/10.5194/gmd-6-1243-2013, 2013.

Nepstad, D.C., Veríssimo, A., Alencar, A., Nobre, C., Lima, E., Lefebvre, P., Schlesinger, P., Potter, C., Moutinho, P., Mendoza, E., Cochrane, M., and Brooks, V.: Large-scale impoverishment of Amazonian forests by logging and fire, Nature, 398, 505-508, 1999.

Oliveira, P. H. F., Artaxo, P., Pires, C., De Lucca, S., Procópio, A., Holben, B., Schafer, J., Cardoso, L. F., Wofsy, S. C., and Rocha, H. R.: The effects of biomass burning aerosols and clouds on the $\mathrm{CO}_{2}$ flux in Amazonia, Tellus B, 59, 338-349, https://doi.org/10.1111/j.1600-0889.2007.00270.x, 2007.

Pereira, G., Siqueira, R., Rosário, N. E., Longo, K. M., Freitas, S. R., Cardozo, F. S., Kaiser, J. W., and Wooster, M. J.: Assessment of fire emission inventories during the South American Biomass Burning Analysis (SAMBBA) experiment. Atmos. Chem. Phys., 16, 6961-6975, https://doi.org/10.5194/acp16-6961-2016, 2016.

Peters, W., Jacobson, A. R., Sweeney, C., Andrews, A. E., Conway, T. J., Masarie, K., Miller, J. B., Bruhwiler, L. M. P., Pétron, G., Hirsch, A. I., Worthy, D. E. J., van der Werf, G. R., Randerson, J. T., Wennberg, P. O., Krol, M. C., and Tans, P. P.: An atmospheric perspective on North American carbon dioxide exchange: CarbonTracker, P. Natl. Acad. Sci. USA, 104, 1892518930, https://doi.org/10.1073/pnas.0708986104, 2007.

Prins, E. M., Feltz, J. M., Menzel, W. P., and Ward, D. E.: An overview of GOES-8 diurnal fire and smoke results for SCAR-B and 1995 fire season in South America, J. Geophys. Res., 103, 31821-31835, https://doi.org/10.1029/98JD01720, 1998.

Procópio, A. S., Artaxo, P., Kaufman, Y. J., Remer, L. A., Schafer, J. S., and Holben, B. N.: Multiyear analysis of Amazonian biomass burning smoke radiative forcing of climate, Geophys. Res. Lett., 31, 1944-8007, https://doi.org/10.1029/2003GL018646, 2004.

Rap, A., Spracklen, D. V., Mercado, L., Reddington, C. L., Haywood, J. M., Ellis, R. J., and Butt, N.: Fires increase Amazon forest productivity through increases in diffuse radiation, Geophys. Res. Lett., 42, 4654-4662, 2015.

Reid, J. S., Koppmann, R., Eck, T. F., and Eleuterio, D. P.: A review of biomass burning emissions part II: intensive physical properties of biomass burning particles, Atmos. Chem. Phys., 5, 799825, https://doi.org/10.5194/acp-5-799-2005, 2005.

Reynolds, R. W., Rayner, N. A., Smith, T. M., Stokes, D. C., and Wang, W.: An improved in situ and satellite SST analysis for climate, J. Climate, 15, 1609-1625, https://doi.org/10.1175/15200442(2002)015<1609:AIISAS>2.0.CO;2, 2002.

Rosário, N., Yamasoe, M. A., Sayão, A., and Siqueira, R.: Multifilter rotating shadowband radiometer calibration for spectral aerosol optical depth retrievals over São Paulo City, Brazil, Appl. Opt., 47, 1171-1176, 2008.

Rosário, N. E., Longo, K. M., Freitas, S. R., Yamasoe, M. A., and Fonseca, R. M.: Modeling the South American regional smoke plume: aerosol optical depth variability and surface shortwave flux perturbation, Atmos. Chem. Phys., 13, 2923-2938, https://doi.org/10.5194/acp-13-2923-2013, 2013.

Rosário, N. M. E.: Variability of aerosol optical properties over South America and the impacts of direct radiative effect of aerosols from biomass burning, $\mathrm{PhD}$ thesis, Institute of Astronomy, Geophysics and Atmospheric Sciences, University of São Paulo, São Paulo, 2011 (in Portuguese).
Rosenfeld, D.: TRMM observed first direct evidence of smoke from forest fires inhibiting rainfall, Geophys. Res. Lett., 26, 31053108, 1999.

Rossato, L., Alvalá, R. C. S., and Tomasella, J.: Distribuição geográfica da capacidade de armazenamento de água e das propriedades físicas do solo no Brasil, in: X Congresso Brasileiro de Meteorologia/VIII Congresso da FLISMET, Brasília, DF, Brazil, 1998 (in Portuguese).

Saleska, S. R., Miller, S. D., Matross, D. M., Goulden, M. L., Wofsy, S. C., da Rocha, H. R., de Camargo, P. B., Crill, P., Daube, B. C., de Freitas, H. C., Hutyra, L., Keller, M., Kirchhoff, V., Menton, M., Munger, J. W., Pyle, E. H., Rice, A. H., and Silva, H.: Carbon in Amazon forests: unexpected seasonal fluxes and disturbanceinduced losses, Science, 302, 1554-1557, 2003.

Schafer, J. S., Eck, T. F., Holben, B. N., Artaxo, P., and Duarte, A. F.: Characterization of the optical properties of atmospheric aerosols in Amazonia from long-term AERONET monitoring (1993-1995 and 1999-2006), J. Geophys. Res., 113, D04204, https://doi.org/10.1029/2007JD009319, 2008.

Sellers, P. J.: Canopy reflectance, photosynthesis and transpiration, Int. J. Remote Sens., 6, 1335-1372, https://doi.org/10.1080/01431168508948283, 1985.

Sestini, M. F., Reimer, E. S., Valeriano, D. M., Alvalá, R. C.S., Mello, E. M.K., Chan, C. S., and Nobre, C. A.: Mapa de cobertura da terra da Amazonia legal para uso em modelos meteorológicos, In: Anais do Simpósio Brasileiro de Sensoriamento Remoto, 11, (SBSR), Belo Horizonte, 2901-2906, 2003.

Setzer, A. and Pereira, M.: Amazonia biomass burnings in 1987 and an estimate of their tropospheric emissions, Ambio, 20, 19-22, 1991.

Sitch, S., Cox, P. M., Collins, W. J., and Huntingford, C.: Indirect radiative forcing of climate change through ozone effects on the land-carbon sink, Nature, 448, 791-794, https://doi.org/10.1038/nature06059, 2007.

Steiner, A. and Chameides, W.: Aerosol-induced thermal effects increase modelled terrestrial photosynthesis and transpiration, Tellus B, 57, 1600-0889, 2011.

Tans, P. P., Bakwin, P. S., and Guenther, D. W.: A feasible global carbon cycle observing system: a plan to decipher today's carbon cycle based on observations, Glob. Change Biol., 2, 309-318, 1996.

Toon, O. B., Turco, R. P., Westphal, D., Malone, R., and Liu, M.: A Multidimensional Model for Aerosols: Description of Computational Analogs, J. Atmos. Sci., 45, 2123-2144, https://doi.org/10.1175/15200469(1988)045<2123:AMMFAD>2.0.CO;2, 1988.

von Randow, C., Manzi, A. O., Kruijt, B., de Oliveira, P. J., Zanchi, F. B., Silva, R. L., Hodnett, M. G., Gash, J. H. C., Elbers, J. A., Waterloo, M. J., Cardoso, F. L., and Kabat, P.: Comparative measurements and seasonal variations in energy and carbon exchange over forest and pasture in South West Amazonia, Theor. Appl. Climatol., 78, 5-26, https://doi.org/10.1007/s00704-004-0041-z, 2004.

Vourlitis, G. L., de Almeida Lobo, F., Zeilhofer, P., and de Souza Nogueira, J.: Temporal patterns of net $\mathrm{CO}_{2}$ exchange for a tropical semideciduous forest of the southern Amazon Basin, J. Geophys. Res., 116, G03029, https://doi.org/10.1029/2010JG001524, 2011. 
Walko, R. L., Cotton, W. R., Meyers, M. P., and Harrington, J. Y.: New RAMS cloud microphysics parameterization. Part I: the single-moment scheme, Atmos. Res., 38, 29-62, https://doi.org/10.1016/0169-8095(94)00087-T, 1995.

Yamasoe, M. A., von Randow, C., Manzi, A. O., Schafer, J. S., Eck, T. F., and Holben, B. N.: Effect of smoke and clouds on the transmissivity of photosynthetically active radiation inside the canopy, Atmos. Chem. Phys., 6, 1645-1656, https://doi.org/10.5194/acp-6-1645-2006, 2006.

Yarwood, G., Rao, S., Yocke, M., and Whitten, G. Z.: Updates to the Carbon Bond chemical mechanism: CB05, Final Report to the US EPA, RT-0400675, Novato, CA, available at: http://www. camx.com/files/cb05_final_report_120805.aspx (last access: 19 July 2016), 2005.
Yu, H., Lui, S. C., and Dickinson, R. E.: Radiative effects of aerosols on the evolution of the atmospheric boundary layer, J. Geophys. Res., 107, AAC 3-1-AAC 3-14, https://doi.org/10.1029/2001JD000754, 2002.

Zobler, L.: Global Soil Types, 1-Degree Grid (Zobler), ORNL DAAC, Oak Ridge, Tennessee, USA, https://doi.org/10.3334/ORNLDAAC/418, 1999. 